\title{
Intergranular and Pitting Corrosion in Sensitized and Unsensitized 20Cr-25Ni-Nb Austenitic Stainless Steel
}

\author{
Ronald N. Clark**, Choen May Chan**, W. Steve Walters***, Dirk Engelberg****, Geraint Williams***** \\ ‡Corresponding author. E-mail: ronald.clark@uknnl.com. \\ *National Nuclear Laboratory, Unit 102B, Sperry Way, National Nuclear Laboratory, Stonehouse, GL10 3UT, UK \\ **Jacobs, Walton House, Faraday street, Birchwood Park, Warrington, WA3 6GA, UK \\ *** National Nuclear Laboratory, Building D5 (First Floor), Culham Science Centre, Abingdon, Oxfordshire, OX14 3DB, UK \\ ****Materials and Performance Centre \& Corrosion and Protection Centre, Department of Materials, The University of Manchester, Manchester M13 9PL, UK \\ *****Swansea University, Materials Research Centre, Bay Campus, Fabian Way, Crymlyn Burrows, Swansea, SA1 8EN, Wales, UK
}

Ronald.clark@uknnl.com (R.N.Clark)

ChoenMay.chan@jacobs.com (C.M. Chan)

Steve.walters@uknnl.com (W.S.Walters)

d.engelberg@manchester.ac.uk (D. Engelberg)

Geraint.williams@swansea.ac.uk (G. Williams)

\section{ABSTRACT}

Advanced gas-cooled reactor (AGR) oxide fuels used in the UK are clad in bespoke grade $20 \% \mathrm{Cr}-25 \% \mathrm{Ni}$ - Nb austenitic stainless steel. Electrochemistry was first applied to correlate the breakdown potential with chloride ion concentration, temperature and $\mathrm{pH}$ for this alloy. At nearneutral $\mathrm{pH}$ the unsensitized material exhibited a linear $\mathrm{E}_{\mathrm{b}}=A+B \log _{10}\left[\mathrm{Cl}^{-}\right]$relationship, where $A=0.7 \mathrm{~V}(\mathrm{vs}$. SCE), and $B=-0.098 \mathrm{~V} /$ decade. Scanning Kelvin probe force microscopy revealed grain boundary regions in the heat-treated material up to $65 \mathrm{mV}$ less noble to the matrix, whereas undissolved niobium carbide $(\mathrm{NbC})$ precipitates were up to $55 \mathrm{mV}$ more noble to the matrix. In-situ time-lapse microscopy and post-corrosion observations confirmed that sensitized grain boundaries were susceptible to pitting corrosion, further developing along intergranular corrosion pathways. It has however been shown that micro galvanic coupling between the Nb precipitates and matrix and / or sensitized grain boundary regions is not a factor in corrosion initiation as all experiments were performed under external potential control. Post-corrosion observations showed the presence of pits at $\mathrm{NbC}$ precipitates promoting grain boundary corrosion. It is postulated that corrosion initiates at NbC precipitates as a pit, and when in close vicinity to $\mathrm{Cr}$-depleted grain boundaries, then propagates along grain boundaries as intergranular corrosion.

KEY WORDS: stainless steel; sensitization; pitting corrosion; intergranular corrosion; afm; skpfm; time lapse microscopy; scanning electron microscopy

\section{INTRODUCTION}

The UK's nuclear advanced gas-cooled reactor (AGR) oxide fuel comprises of $\mathrm{UO}_{2}$ pellets clad in a niobium-stabilized austenitic grade of stainless steel known as "20Cr-25Ni-Nb". AGR fuel pins (about a meter in length) are organized into bundles known as fuel elements, with eight of 
these stacked vertically together to form a stringer ${ }^{(i)}$. Approximately 300 stringers are used in each AGR core for reactor operation, with the core refueled approximately every six years, depending on the extent of burn-up required. ${ }^{1}$ Following use in reactor, spent nuclear fuel (SNF) is removed and allowed to cool in specially engineered ponds, with well-controlled operating chemistry. The current UK strategy is to long-term store SNF (both current, and future arisings, from the UK AGR stations) until a geological disposal facility (GDF) is available. ${ }^{2}$ The quantity of failed cladding arising from pond storage is small, and the UK has over three decades worth of operational experience for AGR fuel in wet storage. ${ }^{3}$ The most susceptible cladding is that present within the lower elements within the stringer(ii), due to a combination of elevated temperature and sufficient neutron flux which can alter the grain boundary microchemistry through the radiation-induced segregation (RIS) process. ${ }^{3-9}$ The radiation-induced compositional changes lead to the depletion of $\mathrm{Cr}$ at grain boundaries, which effectively results in sensitization of the stainless steel. In turn this can lead to initiation and propagation of intergranular corrosion (IGC) if the wet storage environment is sufficiently corrosive. Notably, the upper elements in a stringer are not sensitized in this way; representing approximately $75 \%$ of the fuel pins in the stringer, and the fuel population as a whole. Another method of sensitizing the material is through proton irradiation. A comprehensive study of materials characterization and analysis of the $20 \mathrm{Cr}-25 \mathrm{Ni}-\mathrm{Nb}$ microstructure following proton irradiation ${ }^{10-12}$ and following isothermal annealing ${ }^{13}$ can be found in the works of Barcellini et al.

Once the fuel is removed from the reactor, SNF cools at station ponds for typically three months ${ }^{3}$ prior to transport to the Thermal Oxide Reprocessing Plant ${ }^{(i i i)}$ (THORP) for long-term interim wet storage at Sellafield, UK. Station cooling pond water is borated to provide criticality control (acidic); and neutralized to $\mathrm{pH}$ 7. Following this, at THORP, long-term wet storage takes place in demineralized water with low impurity contents (chloride concentration $\left.\left(\left[\mathrm{Cl}^{-}\right]\right)<0.1 \mathrm{ppm}\right)$, and dosed with $\mathrm{NaOH}(\mathrm{pH} 11.4)$ to inhibit corrosion. ${ }^{3}$ Impurities such as $\mathrm{Cl}^{-}$are well known to increase the susceptibility to corrosion, and so impurities are tightly controlled. ${ }^{3}$ In order to store the expected future arisings of AGR SNF -the UK ceased oxide fuel reprocessing in 2018 - a new racking system has been developed to allow higher density packing of fuel. Modelling has been conducted to assess the impact on pond temperatures, and current estimates point toward an increase from $24{ }^{\circ} \mathrm{C}$ to $45^{\circ} \mathrm{C},{ }^{9}$ with such estimates suggesting that temperatures could rise to $60^{\circ} \mathrm{C}$ in normal operations, and possibly boiling in a fault condition. ${ }^{14,15}$ Whilst the availability of an eventual GDF is some time away, pond storage is anticipated to be required for several decades, significantly beyond the (approximately) three decades experience to date.

Past work has revealed that $\mathrm{NbC}$ precipitates present within the $20 \mathrm{Cr}-25 \mathrm{Ni}-\mathrm{Nb}$ stainless steel microstructure are linked to localized corrosion initiation. ${ }^{8,16}$ Application of the scanning vibrating electrode technique (SVET), combined with scanning electron microscopy energy-dispersive X-ray spectroscopy (SEM-EDS) and focused ion beam SEM (FIB-SEM) apparatus has shown an abundance of Nb-rich precipitates at pit sites. This research also showed the propagation of IGC along grain boundaries, with NbC appearing unaffected using the time-lapse microscopy (TLM) technique. Additionally, electrochemical atomic force microscopy (EC-AFM) highlighted the initiation of a small pit at a grain boundary close to a precipitate, expected to be NbC. SEM-EDS characterization following polarization showed corrosion initiation around NbC precipitates. ${ }^{16}$ What is required is information to link the corrosion pit initiation to the propagation of IGC, which in turn will help explain how intergranular stress corrosion cracking (IGSCC) initiates when sufficient residual stresses are present. ${ }^{17}$ In this paper an electrochemical investigation is conducted to give insight into the dependence of key parameters $\left(\left[\mathrm{Cl}^{-}\right]\right.$, temperature, $\left.\mathrm{pH}\right)$ on the corrosion of this austenitic $20 \mathrm{Cr}$ - $25 \mathrm{Ni}-\mathrm{Nb}$ stainless steel in an as-received,

\footnotetext{
(i) Dungeness B fuel stringers utilise 7 fuel elements

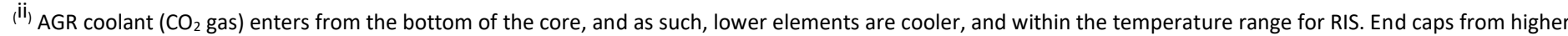
elements can also be susceptible to sensitization at higher fuel burn-up

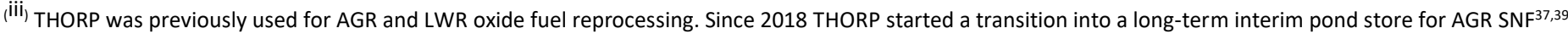


unsensitized condition. Following the initial study on unsensitized $20 \mathrm{Cr}-25 \mathrm{Ni}-\mathrm{Nb}$, the alloy is studied in a thermally sensitized condition to investigate the link between apparent pitting corrosion and IGC propagation. Research on the IGC-susceptible RIS form of the alloy - which is subjected to pond storage after in-service use - is typically restricted to activities in shielded "hot" cells or activities using size-reduced specimens (e.g. transmission electron microscope foils). Thermally sensitized material is utilized as a "safe" analogue for this research, which also enabled the use of techniques which would otherwise be unavailable in a hot cell, or incompatible with size-reduced material. By comparing the localized corrosion initiation, and propagation, of both the as-received, and thermally sensitized forms of the alloy, the project objective is to clarify whether or not sensitization has any influence on the initiation mechanism. This research was conducted between three different institutions, who independently noted the same observations..$^{\text {iv }}$ )

\section{EXPERIMENTAL}

AGR fuel cladding, $20 \mathrm{Cr}-25 \mathrm{Ni}-\mathrm{Nb}$ stainless steel, was obtained from Westinghouse, UK, as flat strip “end cap" material ( $350 \times 25 \times 0.8 \mathrm{~mm}$ ) and tube material (150 mm diameter, $0.38 \mathrm{~mm}$ wall thickness). The flat strip material is used during production to form "end caps" by forming into a thimble-shaped cap, then roller spot welding to the same alloy, in tube form, to form fuel pins. Note that AGR fuel cladding tube has a series of helical ribs on the outside, used to promote turbulent mixing of the $\mathrm{CO}_{2}$ gas coolant. An example of the tube and helical ribs is shown in Figure 1 . The composition of the alloy is given in Table 1 for both the end cap and tube material. ${ }^{16}$ Both end cap flat strip and tube material were used within this work. Heat treatments were conducted to both stabilize and thermally sensitize the alloy (end cap and tube) following the procedure described in ${ }^{8}$ For the stabilization treatment, sample material was solution annealed at $120{ }^{\circ} \mathrm{C}$ in an $\mathrm{Ar}$ atmosphere for an hour, followed by a water quench. Aging of the material was then conducted at $930{ }^{\circ} \mathrm{C}$ in air for a period of 40 minutes. The sensitization heat treatment involved a $1150{ }^{\circ} \mathrm{C}$ solution anneal for a period of 30 minutes, followed by a water quench. The aging treatment for thermal sensitization was $600{ }^{\circ} \mathrm{C}$ for a period of 2 weeks. The aim of stabilization was to mimic the final heat treatment step used during manufacturing, to produce a microstructure that should be similar to that which enters service. The higher temperature solution anneal serves to both decrease residual stress from manufacturing process, and dissolve NbC into the matrix. The lower temperature $930{ }^{\circ} \mathrm{C}$ treatment serves to then reprecipitate $\mathrm{NbC}$ to remove free $\mathrm{C}$ within the matrix.

End cap flat strip specimens were cut into $\sim 15 \mathrm{~mm}^{2}$ specimens, ground (P180-P2000), then polished using 6 and $1 \mu \mathrm{m}$ diamond suspension A bespoke polytetrafluoroethylene (PTFE) working electrode holder was used during electrochemistry experiments (open circuit potential (OCP) and potentiodynamic polarization) in order to provide a constant exposed area (11.31 $\mathrm{mm}^{2}$ ) and electrical connection to a potentiostat (Gamry Interface 1000, Ivium Compactstat, or Solartron 1280b). Preparation of the tube sample material was as follows. The tube was first cut using a linear precision saw, the helical outer ribs ground away (helical ribs shown in Figure 1), then ground and polished (final step $1 \mu \mathrm{m}$ diamond suspension), a wire spot welded to the back surface, and then finally masked with non-conductive lacquer (Lacomit) so as to only expose the front polished surface. The reader should be aware that the material is particularly prone to crevice corrosion after masking an exposed area. This was true when the electrode holder, PTFE or non-conductive lacquer were used, and in some circumstances crevice corrosion occurred. If crevice corrosion was found to be present visually, following OCP / potentiodynamic polarization d.c. electrochemistry experiments (PTFE holder), the results were excluded, and the experiment was repeated.

${ }^{\text {iv }}$ ) As different institutions were utilized there were differences in the instrumentation and equipment, for example, the type of potentiostat or SEM used. 


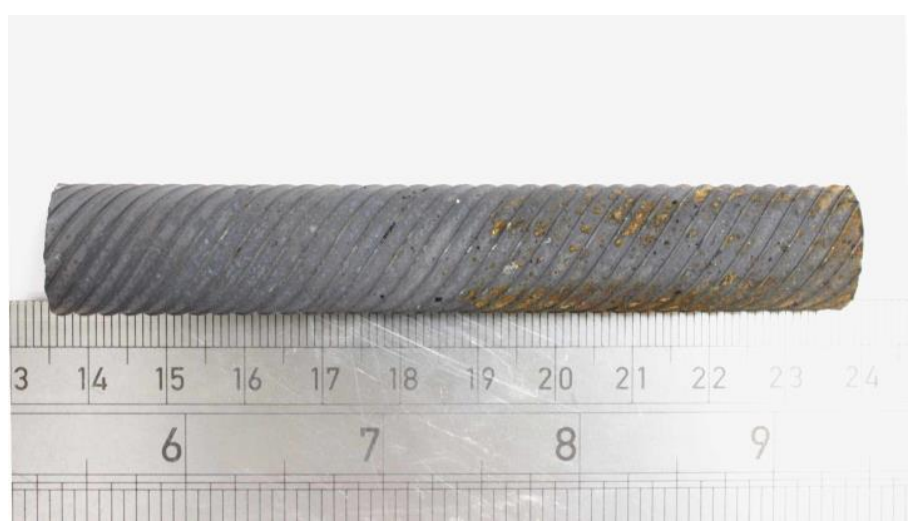

Figure 1: Example image of sensitized AGR fuel cladding in tube form, showing the outer helical ribs. Image taken after a corrosion experiment had taken place

Table 1: Composition of AGR fuel cladding tube and end cap using inductively coupled plasma-optical emission spectroscopy (ICP-OES, values in weight $\%, N / D=$ not detected $)^{(\mathrm{V}) 16}$

\begin{tabular}{|l|l|l|l|l|l|l|l|l|l|l|l|l|l|}
\hline & $\mathbf{F e}$ & $\mathbf{C r}$ & $\mathbf{N i}$ & $\mathbf{N b}$ & $\mathbf{C}$ & $\mathbf{S i}$ & $\mathbf{M n}$ & $\mathbf{S}$ & $\mathbf{P}$ & $\mathbf{N}$ & $\mathbf{M o}$ & $\mathbf{T i}$ & $\mathbf{B}$ \\
\hline Tube & Bal & 19.7 & 24.6 & 0.65 & 0.049 & 0.57 & 0.75 & $<0.003$ & 0.01 & 0.015 & 0.01 & N/D & N/D \\
\hline $\begin{array}{l}\text { End } \\
\text { cap }\end{array}$ & Bal & 19.4 & 25.5 & 0.61 & 0.052 & 0.53 & 0.70 & 0.008 & 0.004 & 0.1 & 0.03 & 0.035 & 0.0007 \\
\hline
\end{tabular}

\subsection{Electrochemistry}

The potentiostat was used in a three-electrode cell configuration, with the specimen connected as a working electrode, Pt (either gauze or wire) as a counter electrode, and a reference electrode (either saturated calomel electrode (SCE), graphite, or silver-silver chloride (Ag/AgCl)). Prior to potentiodynamic polarization, working electrodes were immersed in the electrolyte for a period of 30 minutes. During this period, the electrolyte was sparged with $\mathrm{N}_{2}$ gas, and the vessel covered. Thereafter, a slow trickle of $\mathrm{N}_{2}$ gas was allowed to flow into the headspace. For the [Cl'] dependence experiments $0.01,0.05,0.20,1.0 \mathrm{~mol} \cdot \mathrm{dm}^{-3} \mathrm{NaCl}$ electrolytes were used. The starting potentials used in the potentiodynamic experiments were 200 $\mathrm{mV}$ negative of the measured open circuit potential and were scanned with a $0.5 \mathrm{mV} \cdot \mathrm{s}^{-1}$ rate. Linear regression was used to fit the dependence curves, using weighting for error at each interval. Three repeat measurements were taken; with the error bars in each graph representing one standard deviation of the mean (any outliers were excluded from the fit). In addition to the potentiodynamic experiments, a series of open circuit potential (OCP) experiments were conducted in open air to determine $E_{c o r r}$ without the influence of perturbation or $N_{2}$ sparging. Breakdown potential ( $E_{b}$ ) was defined as the potential in which there was a sharp, sustained increase in current density following the passive region of the potentiodynamic curve. ${ }^{18}$ For $\mathrm{T}$ and $\mathrm{pH}$ dependence experiments, $\left[\mathrm{Cl}^{-}\right]$was fixed at $1 \mathrm{~mol} \cdot \mathrm{dm}^{-3}$. To create acidic and basic environments droplets of $\mathrm{NaOH}$ or $\mathrm{HCl}$ were added to the chloride electrolyte by Pasteur pipette and checked against a $\mathrm{pH}$ probe to obtain the required $\mathrm{pH}(\mathrm{pH} 2.5,7,11.4,12.5)$. A water bath was

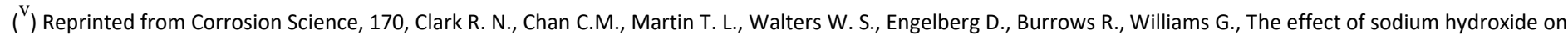
niobium carbide precipitates in thermally sensitised $20 \mathrm{Cr}$-25Ni-Nb austenitic stainless steel, 108596, Copyright 2020, with permission from Elsevier. 
used to vary the electrolyte temperature $\left(20,30,40,50,60,80^{\circ} \mathrm{C}\right)$, and the SCE potential was corrected according to the formula shown in Equation $1^{19}\left(T_{K}=\right.$ temperature in Kelvin, $E=$ potential in volts $)$.

Equation 1 SCE temperature correction

$$
E_{S H E}=E_{S C E}+0.242-7.6 \times 10^{-4}\left(T_{K}-298\right)
$$

\subsection{Characterization and Analysis}

Thermally sensitized end cap specimens were mounted in a cold-set resin, ground (P180 to P2000), and then polished using 6 and $1 \mu$ m diamond suspension. Where required, an electrolytic etch was used to reveal grain boundaries using $10 \% \mathrm{w} / \mathrm{v}$ oxalic acid (6 V d.c. polarization, $10 \mathrm{~s}$ ). Micrographs of the unsensitized and sensitized microstructures were taken using a Nikon MA200 inverted microscope with 100x objective. An AFM with SKPFM capability was used in non-contact AC mode (hover set to $50 \mathrm{~nm}$ ) to record topography (trace), and Volta potential (retrace) over a $50 \mu \mathrm{m}^{2}$ area $^{(\mathrm{vi})}$ (512 $\times 512$ pixel resolution). Non-contact Nanoworld FM50 cantilevers were used for AFM/SKPFM measurement. To provide an electrical connection to the instrument for SKPFM, copper foil was applied away from the area of interest. SKPFM Volta potentials were inverted according to convention (lighter areas more noble). Optical TLM experiments were conducted using a 20 x objective lens (with 0.7 x C-mount) covered by waterproof shroud, allowing it to be immersed in the electrolyte. The same preparation process was used for the TLM specimens, differing only in that a wire was spot welded to the bottom of the specimen prior to it being set in resin. The wire provided an electrical connection to a Palmsens 3 battery-powered potentiostat. To only expose only a small region of interest on the specimen, a small hole was perforated in PTFE tape (HD5490) using a $0.5 \mathrm{~mm}$ biopsy pen, the tape was then placed onto the surface. The reader should be aware that the PTFE tape did not always provide a water-tight seal, and in some circumstances led to crevice corrosion. Specimens were analyzed by a combination of SEM-EDS microscopes which included: Hitachi TM3000, Zeiss Evo 50, Zeiss Sigma HD VP (field emission gun SEM (FEG-SEM)) and FEI Quanta 650.

\section{RESULTS}

\subsection{As-received, Unsensitized End-cap Alloy}

Figure 2(i) shows the results of potentiodynamic polarization in $\mathrm{NaCl}$ electrolytes. The most positive breakdown potential $\left(\mathrm{E}_{\mathrm{b}}\right)$, was observed at the lowest electrolyte concentration $\left(0.01 \mathrm{~mol} \cdot \mathrm{dm}^{-3}\right)$ with an average difference in potential $\left(\Delta E=E_{b}-E_{c o r r}=744 \mathrm{mV}\right)$. The average change in potential $(\Delta \mathrm{E})$ in $0.05 \mathrm{~mol} \cdot \mathrm{dm}^{-3}$ was smaller $(680 \mathrm{mV})$, which was similar to that observed in $0.2 \mathrm{~mol} \cdot \mathrm{dm}^{-3}(678 \mathrm{mV})$. The average $\Delta \mathrm{E}$ reduced to $613 \mathrm{mV}$ at the highest concentration used $\left(1 \mathrm{~mol} \cdot \mathrm{dm}^{-3}\right)$. Throughout the experiments the passive anodic current density values were found to reside within the range of previously reported values $\left(10^{-6} \mathrm{~A} \cdot \mathrm{cm}^{-2}\right)$ for American Iron and Steel Institute (AISI) 304 (EN 1.4301/UNS S30400), another austenitic stainless steel. ${ }^{20}$ In all cases transient events were observed, which can be an indicator of passive film breakdown. As would be expected, the results show a linear trend of decreasing $\mathrm{E}_{\mathrm{b}}$ with increasing $[\mathrm{Cl}]$; which are linked by a linearized relationship $\left(\mathrm{E}_{\mathrm{b}}=\mathrm{A}+\mathrm{B} \log _{10}[\mathrm{Cl}]\right){ }^{20,21} \mathrm{Figure} 2(\mathrm{ii})$ shows a plot of $E_{c o r r}$ and $E_{b}$ as a function of the logarithm of $\left[\mathrm{Cl}^{-}\right]$. A negative linear dependence was observed with $E_{b}$, such that $A=0.7 \vee(v s$. SCE) and $B=-0.098 \pm 0.016 \mathrm{~V} /$ decade. Included within this plot are values of $\mathrm{E}_{\text {corr }}$, derived from separate aerated OCP experiments, which also show a negative linear dependence with the logarithm of chloride concentration. These are in comparison to $\mathrm{E}_{\text {corr }}$ values shown in the potentiodynamic experiments $\left(\mathrm{N}_{2}\right.$-sparged electrolyte) which did not show a clear relationship with chloride concentration. The alloy used in this study (20Cr-25Ni-Nb stainless steel) has been compared to other austenitic stainless steels through the use of a simple empirically-derived formula known as the pitting resistance

(vi) Images were also cropped to form $9.96 \mu \mathrm{m}^{2}$ images using the following pixel dimensions: $X=202, Y=100$, width 102 , height 102 and $X=211, Y=179$, width $=102$, height $=102$ 
equivalent number $\left(\right.$ PREN $\left.^{\left({ }^{\text {vii }}\right)}=\mathrm{Cr}+3.3 \mathrm{Mo}+16 \mathrm{~N}\right) .{ }^{22}$ Take for example, AISI 302, which has a typical PREN value between $17-20,{ }^{23}$ this is compared to AISI 304, which has a similar composition but with slightly higher C, and a PREN within the same range $(18.6)^{20}$. AISI 316, which has a higher Ni content and Mo alloying (2-3 \%) has a PREN of 23.1. ${ }^{23} 20 \mathrm{Cr}$-25Ni-Nb stainless steel has a PREN of 19.7 for the end cap material, and 20.0 for the tube material, lower than that of AISI 316. Values for $\mathrm{E}_{\mathrm{b}}$ were obtained from literature for these alloys in $1 \mathrm{~mol} \cdot \mathrm{dm}^{-3} \mathrm{NaCl}_{\text {and }}$ plotted graphically in Figure 3. The plot shows that whilst $20 \mathrm{Cr}-25 \mathrm{Ni}-\mathrm{Nb}$ has a lower PREN, it has an elevated breakdown potential when compared to AISI 302,304 , and 316.
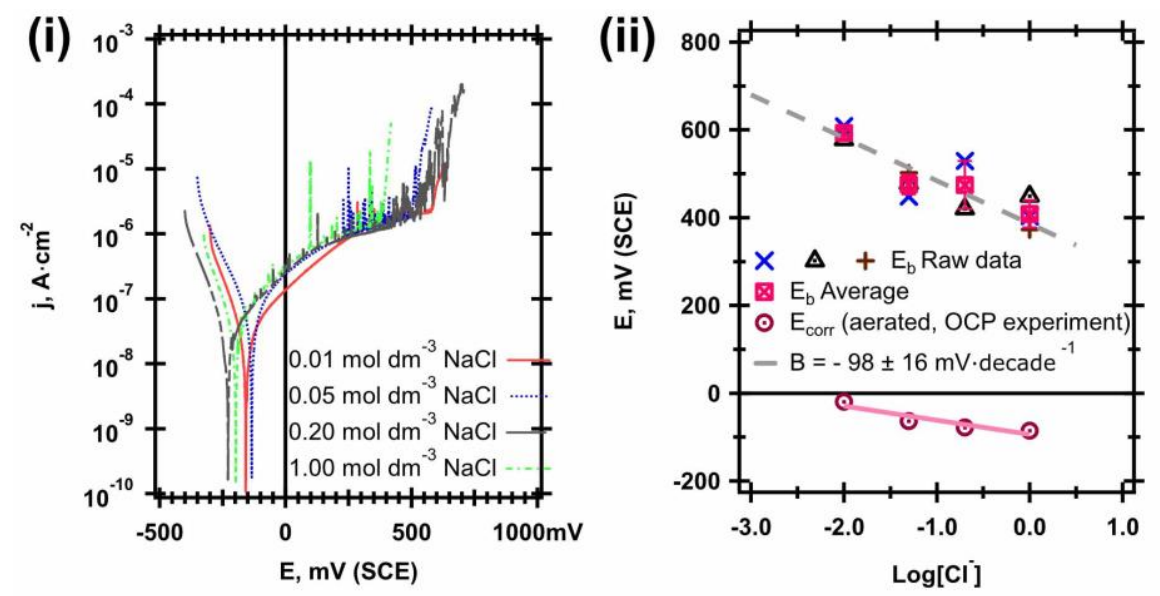

Figure 2: (i) Potentiodynamic polarization curves for the unsensitized alloy in $0.01,0.05,0.20,1.00 \mathrm{~mol} \cdot \mathrm{dm}^{-3} \mathrm{NaCl}$ electrolytes at room temperature $\left(20^{\circ} \mathrm{C}\right.$ ), (ii) chloride dependence curves for the unsensitized alloy showing the variation in $\mathrm{E}_{\text {corr }}$ (from separate aerated OCP experiment) and $\mathrm{E}_{\mathrm{b}}$ at fixed temperature and $\mathrm{pH}$. The $\mathrm{B}$ constant relates to the linear fit for $\mathrm{E}_{\mathrm{b}}$ vs $\log \left[\mathrm{Cl}^{-}\right]$

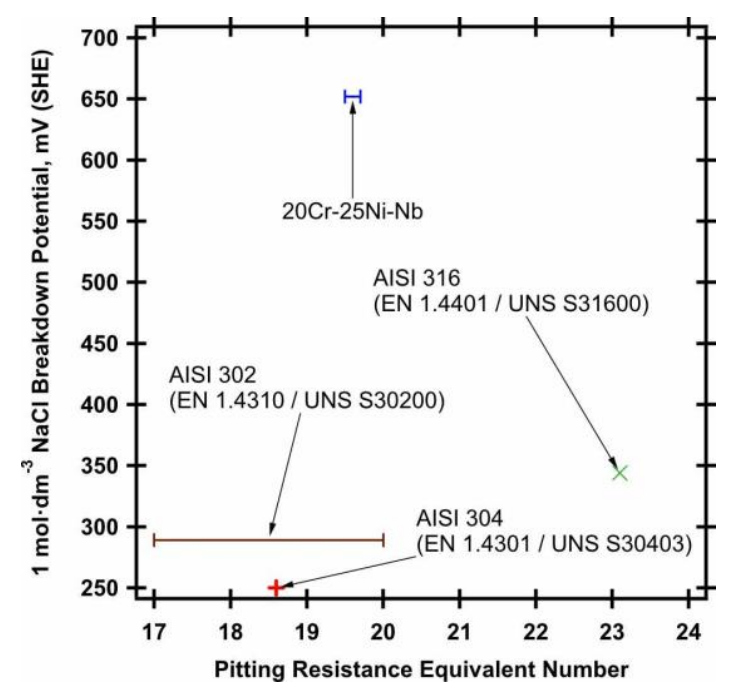

Figure 3: Comparison of breakdown potentials in $1 \mathrm{~mol} \cdot \mathrm{dm}^{-3} \mathrm{NaCl}$ for different austenitic stainless steels as a function of PREN. The PREN for AISI 302 has a wide range due to the alloy specification range. The PREN range for $20 \mathrm{Cr}-25 \mathrm{Ni}-\mathrm{Nb}$ relates to the tube and end cap alloy compositions

Notes: Data for 302, 316 stainless steels obtained from ${ }^{23}$ (120 grit surface finish) Data for 304 stainless steel obtained from ${ }^{23}$

$20 \mathrm{Cr}-25 \mathrm{Ni}-\mathrm{Nb}, 302$ and $316 \mathrm{E}_{\mathrm{b}}$ converted from vs SCE to vs SHE (+244 mV) Composition of 302 stainless steel obtained from ${ }^{24}$

${ }^{\text {(vii) }}$ A multiplier of 16 is not always used for $\mathrm{N}$, and can range from $12.8-30 .{ }^{30,40}$ 
Figure $4(i)$ shows the results of the potentiodynamic polarization at fixed $\left[\mathrm{Cl}^{-}\right]\left(1 \mathrm{~mol} \cdot \mathrm{dm}^{-3}\right)$ over the temperature range $20-80{ }^{\circ} \mathrm{C}$. The results show a decrease in $\mathrm{E}_{\mathrm{b}}$ with temperature, with $\mathrm{E}_{\text {corr }}$ being maintained $\sim-125 \mathrm{mV}$ (SCE) over the range $30-80{ }^{\circ} \mathrm{C}$. Passive current densities remained below $10^{-6} \mathrm{~A} \cdot \mathrm{cm}^{-2}$ at temperatures between $20-60^{\circ} \mathrm{C}$ (at $80^{\circ} \mathrm{C}$ current densities above $10^{-6} \mathrm{~A} \cdot \mathrm{cm}^{-2}$ are realized). The $A$ and $B$ parameters in the linear relationship $\left(E_{b}=A+B \log _{10}\left[\mathrm{Cl}^{-}\right]\right)^{20,21}$ are temperature dependent, with $E_{b}$ shifting toward less noble potentials with increasing temperature above the critical pitting temperature. Figure 4 (ii) shows the plot of $E_{b}$ as a function of temperature.
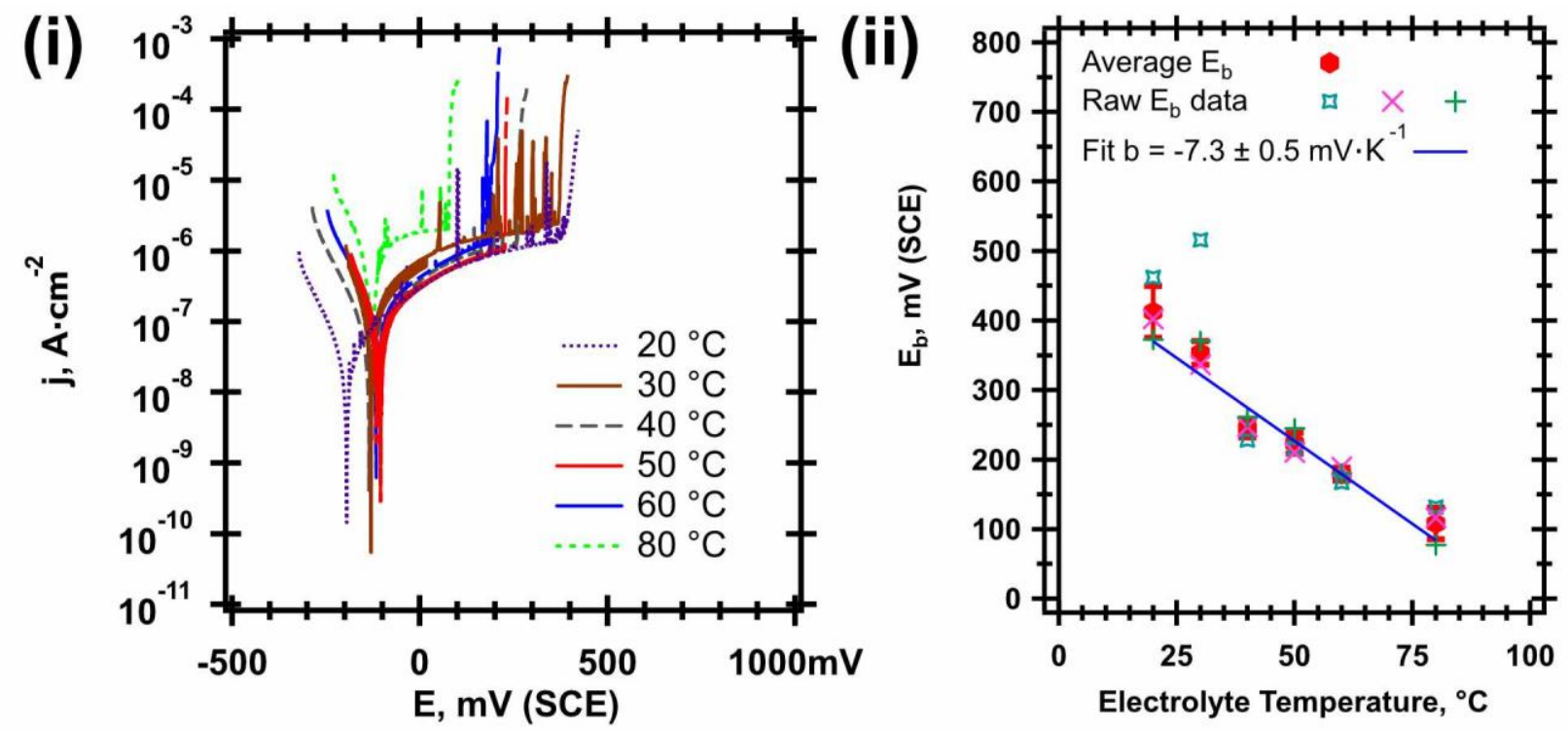

Figure 4: (i) Potentiodynamic polarization curves for the unsensitized alloy in $1 \mathrm{~mol} \cdot \mathrm{dm}^{-3} \mathrm{NaCl}$ as a function of temperature $\left(20,30,40,50,60,80{ }^{\circ} \mathrm{C}\right)$, (ii) temperature dependence curves for the unsensitized alloy in $1 \mathrm{~mol} \cdot \mathrm{dm}^{-3} \mathrm{NaCl}$ at fixed concentration and $\mathrm{pH}$

The effect of $\mathrm{pH}$ is shown in the potentiodynamic polarization curves in Figure 5(i). The effects of acidification can be seen by the distinct peak in the anodic branch of the Tafel slope at $E_{\text {corr }}$ compared to the curve at neutral $\mathrm{pH}$. This environment shows the greatest corrosion current at open circuit $\left(\mathrm{i}_{\text {corr }}\right)$. The acidic environment shows the smallest change in potential $(\Delta \mathrm{E})$. Interestingly, at elevated $\mathrm{pH}(11.4$ and 12.5$)$ the curves show a distinct increase in the passive current density compared to the neutral environment, which is in line with observations on thermally sensitized $20 \mathrm{Cr}-25 \mathrm{Ni}-\mathrm{Nb}$ in $\mathrm{NaOH} .{ }^{16}$ Despite the elevated passive current densities with respect to $\mathrm{pH} 7$, the $\mathrm{pH} 11.4$ and $\mathrm{pH} 12.5$ environments showed the largest $\Delta \mathrm{E}$. Another point to note is the very low $\mathrm{E}_{\mathrm{b}}$ observed in $\mathrm{pH} 11.4$, with the average being between that of $\mathrm{pH} 2.5$ and 7, which was observed in three repeat experiments. If the result at pH 12.5 is excluded, Figure 6(ii) shows little $\mathrm{pH}$ dependence on $\mathrm{E}_{\mathrm{b}}(9.4 \mathrm{mV} / \mathrm{pH})$. 

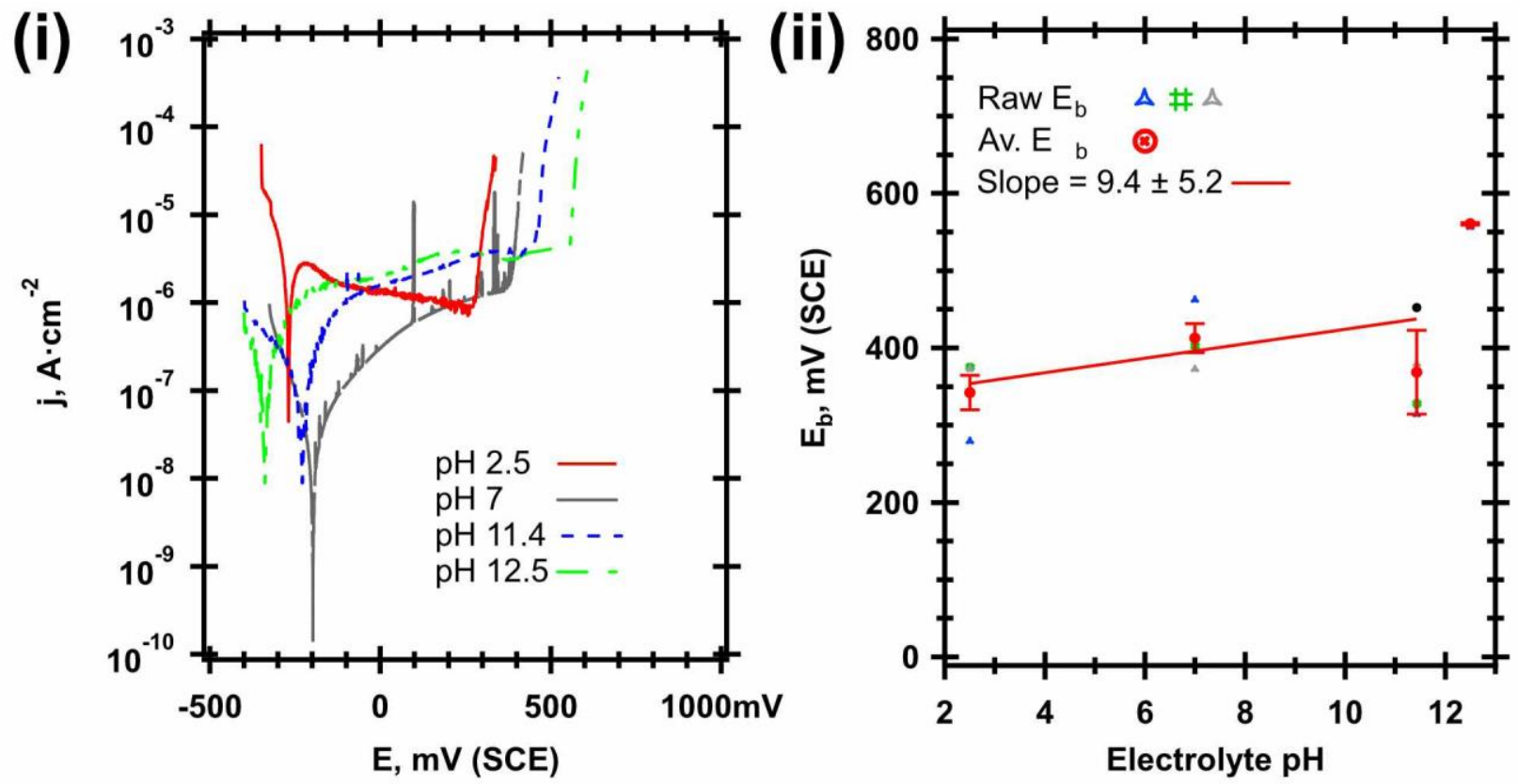

Figure 5: (i) The effect of $\mathrm{pH}$ for the unsensitized alloy in $1 \mathrm{~mol} \cdot \mathrm{dm}^{-3} \mathrm{NaCl}$, as a function of $\mathrm{pH}$ (ii) $\mathrm{pH}$ dependence curves showing the variance of $\mathrm{E}_{\text {corr }}$ and $\mathrm{E}_{\mathrm{b}}$ at different $\mathrm{pH}(2.5,7,11.4,12.5)$ in $1 \mathrm{~mol} \cdot \mathrm{dm}^{-3} \mathrm{NaCl}$ at fixed temperature

Post corrosion SEM images following polarization in $0.01 \mathrm{~mol} \cdot \mathrm{dm}^{-3} \mathrm{NaCl}$ are shown in Figure 6. These illustrate that the mode of corrosion for the unsensitized, as-received material is pitting. Figure 6 (i) shows what appears to be the early stages of localized corrosion, i.e. initiation, centered around several $\mathrm{NbC}$ precipitates. The possibility does exist that $\mathrm{Nb}$ carbides act as local stress raisers, and thus some of the features highlighted could be cracks or crevices which were present prior to experiment, which then led to the formation of metastable pits. Figure 6 (ii) shows both initiation around these precipitates and a pit adjacent to a $\mathrm{NbC}$ precipitate. Importantly, there is no grain boundary attack, or transition from pitting, in line with the expectation. These precipitates have also been shown, at higher [ $\left.\mathrm{Cl}^{-}\right]$, in earlier works to be expelled from the pit itself and reside on the surfaces outside of the pit. ${ }^{8}$
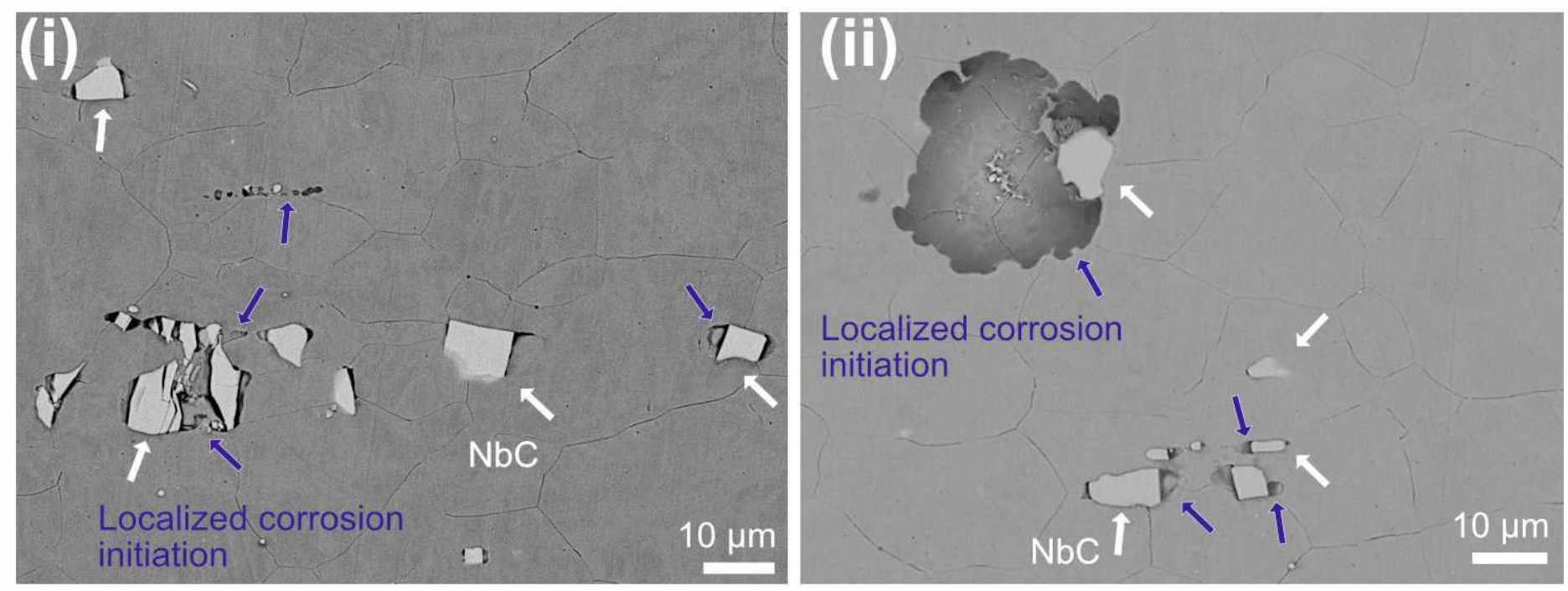

Figure 6: Localized corrosion present on the unsensitized material following polarization in $0.01 \mathrm{~mol} \cdot \mathrm{dm}{ }^{-3} \mathrm{NaCl}$ at $\mathrm{pH} 11.4$ ( $\mathrm{NaOH}$ ). (i) localized pitting corrosion initiation around $\mathrm{NbC}$ precipitates, (ii) pit propagation around an $\mathrm{NbC}$ precipitate 


\subsection{Heat-treated Alloys}

A thermal treatment was conducted on as-received flat strip end cap to simulate the final heat treatment process step conducted during manufacturing, resulting in a Nb-stabilized microstructure. In addition, a thermal treatment was conducted to thermally sensitize the alloy. For metallography and electrochemical comparison of the as-received, stabilized and sensitized microstructures the reader is referred to prior work. ${ }^{25}$ Figure 7 shows micrographs of the as-received and thermally sensitized microstructures. In the micrographs NbC precipitates (shown by arrows) can be seen both within the grains, and in close vicinity to, or residing at grain boundaries.
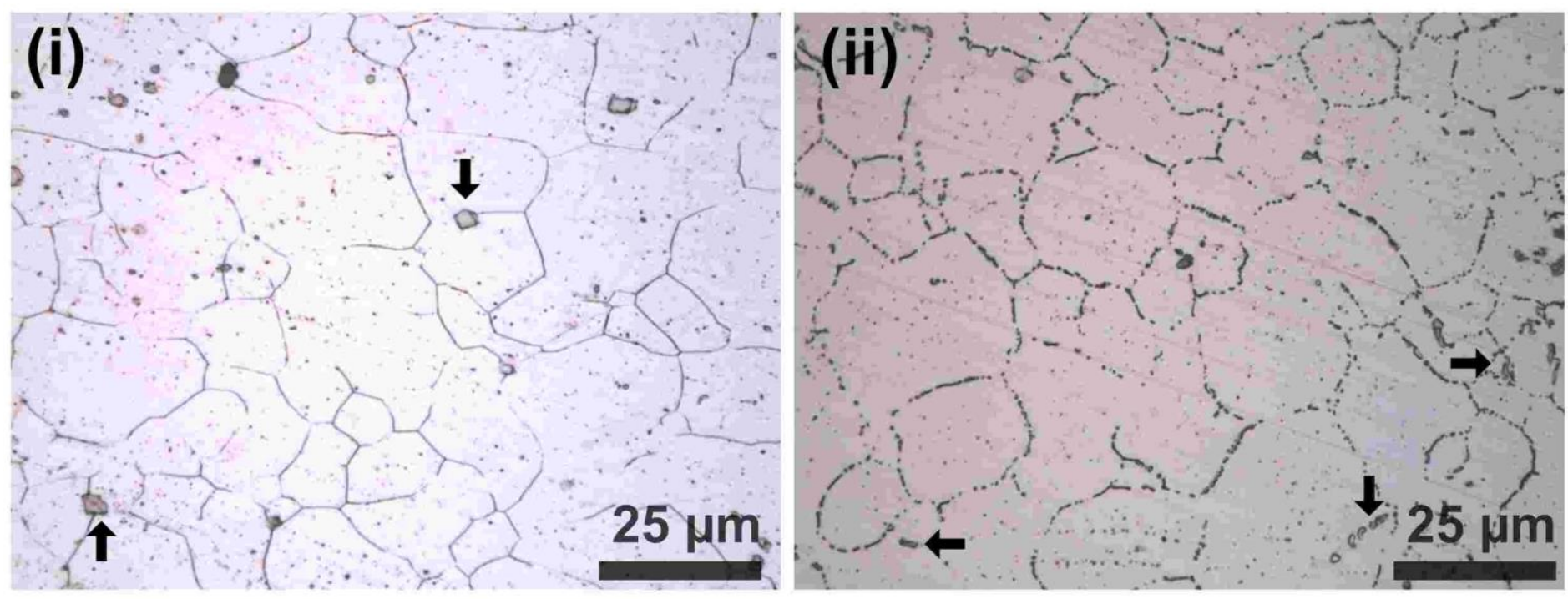

Figure 7: Optical micrographs of the (i) as-received unsensitized microstructure, (ii) thermally sensitized microstructure. The arrows highlight some of the locations where $\mathrm{NbC}$ precipitates are present at, or in close vicinity to, grain boundaries.

\subsubsection{Stabilized End-cap Alloy}

Specimens were subjected to potentiodynamic polarization to $E_{b}$, and then imaged so that the localized corrosion morphology could be studied. As shown in the optical micrograph in Figure 8(i), localized corrosion in the stabilized alloy takes the form of pitting (polarized, 500 ppm [Cl ] $\approx 0.014 \mathrm{~mol} \cdot \mathrm{dm}^{-3} \mathrm{NaCl}$ at $\mathrm{pH} 7$ ). As is typical of stainless steels, lacy covers were found to be present, which assist in restricting mass transport, keeping the pit cavity concentrated with aggressive anions and restricting $\mathrm{O}$ diffusion, thereby assisting in maintaining pit stability. Some lacy pit covers were removed accidentally between the experiment and observation (during the SEM preparation process). This however meant that the cavity within such pits could be studied, which would otherwise be difficult without other methods (e.g., focused ion beam sectioning, x-ray computed tomography), or removal by sonication. Observation by SEM (Figure 8(ii, iii)) revealed the presence of precipitates both at the edge and within the center of pits. SEM-EDS analysis revealed that these precipitates were $\mathrm{Nb}$-rich, and therefore expected to be $\mathrm{NbC}$. This is in line with previous analyses using SEM-EDS and SIMS which have confirmed the presence of $\mathrm{Nb}$ and $\mathrm{C}$ within these precipitates. ${ }^{8}$ Herein, these precipitates will be referred to as $\mathrm{NbC}$. Similar observations were found when polarized in more dilute electrolytes $\left(50 \mathrm{ppm}\left[\mathrm{Cl}^{-}\right] \approx 0.0014 \mathrm{~mol} \cdot \mathrm{dm}^{-3} \mathrm{NaCl}\right.$ at $\left.\mathrm{pH} 7\right)$ but at elevated temperature. Figure $8(\mathrm{v})$ shows: (i) initiation, where a pit had started to form around a small cluster of $\mathrm{NbC}$ precipitates; and (ii) the extent of propagation, where a pit had formed, centered around another cluster of $\mathrm{NbC}$ precipitates with a protective lacy cover. Decreasing the [ $\left.\mathrm{Cl}^{-}\right]$again by a factor of five (10 ppm $\left[\mathrm{Cl}^{-}\right] \approx 28.2 \mathrm{mmol} \cdot \mathrm{dm}^{-3} \mathrm{NaCl}$ at pH 7), and observing the specimens after polarization highlighted the presence of smaller pits on the surface, many of which contained $\mathrm{NbC}$ precipitates (Figure 8(vii-x)). 


\section{0 ppm [Cl]}
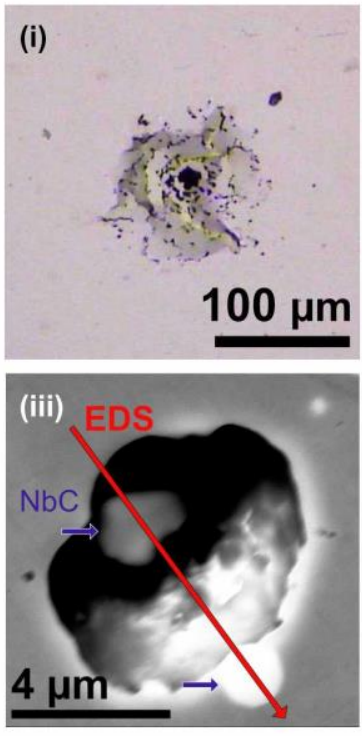

\section{0 ppm [Cl-]}

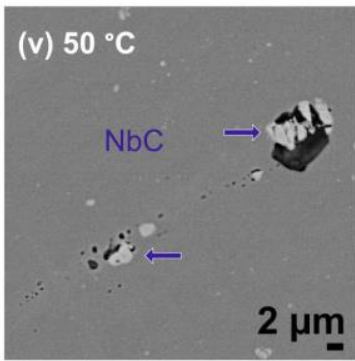

$10 \mathrm{ppm}[\mathrm{Cl}]$
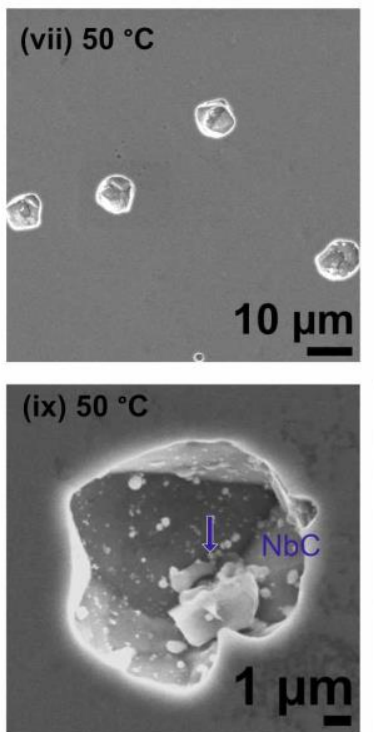

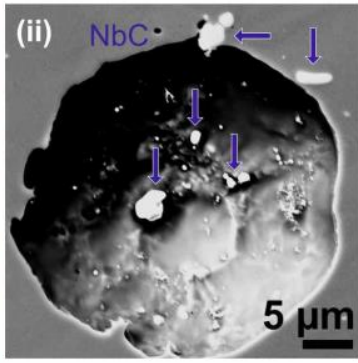

(iv) CPS

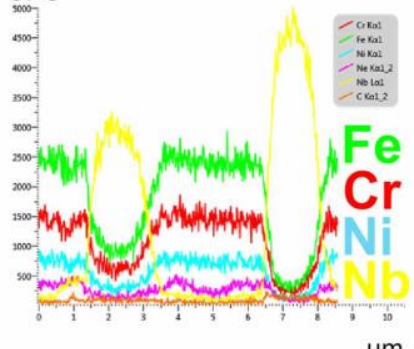

$\mu \mathrm{m}$
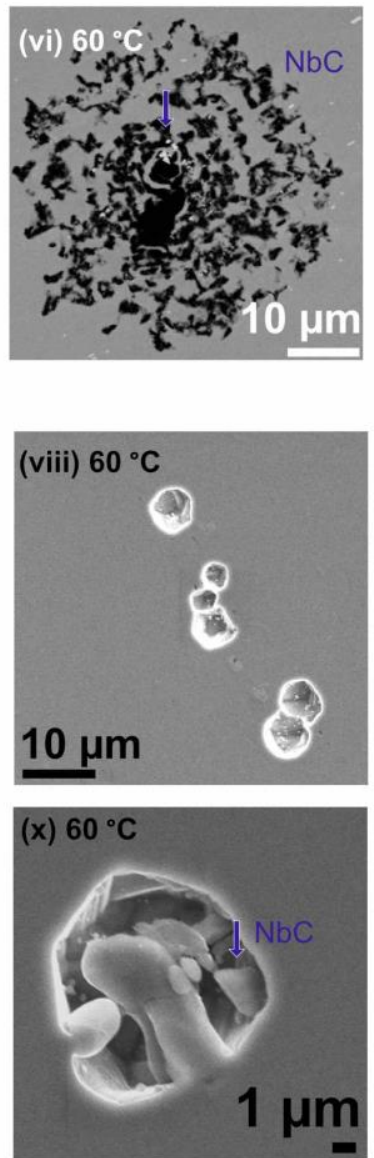

Figure 8: Localized corrosion morphologies for the stabilized end-cap microstructure following potentiodynamic polarization in a range of chloride

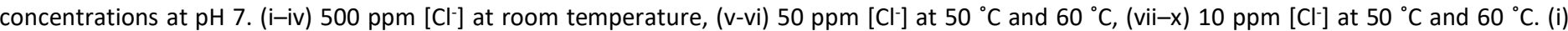
optical micrograph of a pit with lacy cover, (ii, iii) SEM micrographs showing pits that had formed, with $\mathrm{NbC}$ precipitates in the center. The red line in (iii) corresponds to the EDS line scan shown in (iv). (v) pit initiation at a cluster of NbC precipitates, (vi) large pit with lacy cover centered around a small cluster of $\mathrm{NbC}$ precipitates, (vii, viii) small pits with $\mathrm{NbC}$ present, with a detailed view shown in (ix, $\mathrm{x}$ ) 


\subsubsection{Sensitized End-cap and Tube Alloys}

Corrosion site mapping was conducted on the thermally sensitized microstructure by use of SKPFM, shown in Figure 9. As would be expected of a sensitized microstructure, Figure 9(i) shows $\mathrm{Cr}$ carbides which are located at grain boundaries, which jut out of the microstructure, whilst Figure 9(ii) shows the corresponding SKPFM Volta potential map. Figure 9(iii) shows a precipitate, expected to be NbC, which did not dissolve in the solution anneal. The corresponding SKPFM map is shown in Figure 9(iv), highlighting the nobility of the NbC precipitate, compared to the matrix and grain boundary regions. Figure $9(\mathrm{v})$ and Figure $9(\mathrm{vi})$ show AFM and SKPFM maps of a triple point grain boundary which shows depressions in Volta potential at this region. This information is in agreement with past work ${ }^{8}$ where $\mathrm{NbC}$ were observed to have elevated Volta potentials with respect to the matrix, and the grain boundary regions show more negative Volta potentials compared to the matrix. A Volta potential cross section of the $\mathrm{NbC}$ precipitate and a grain boundary region is shown in Figure 9(vii), which shows how the two regions differ in Volta potential. The negative Volta potentials observed at grain boundary regions are up to $65 \mathrm{mV}$ less noble than the matrix. NbC precipitates are, in comparison, up to $55 \mathrm{mV}$ more noble than the matrix.

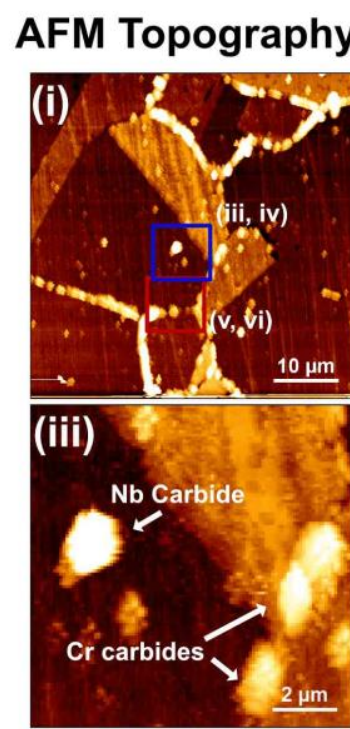

\section{SKPFM Volta Potential}
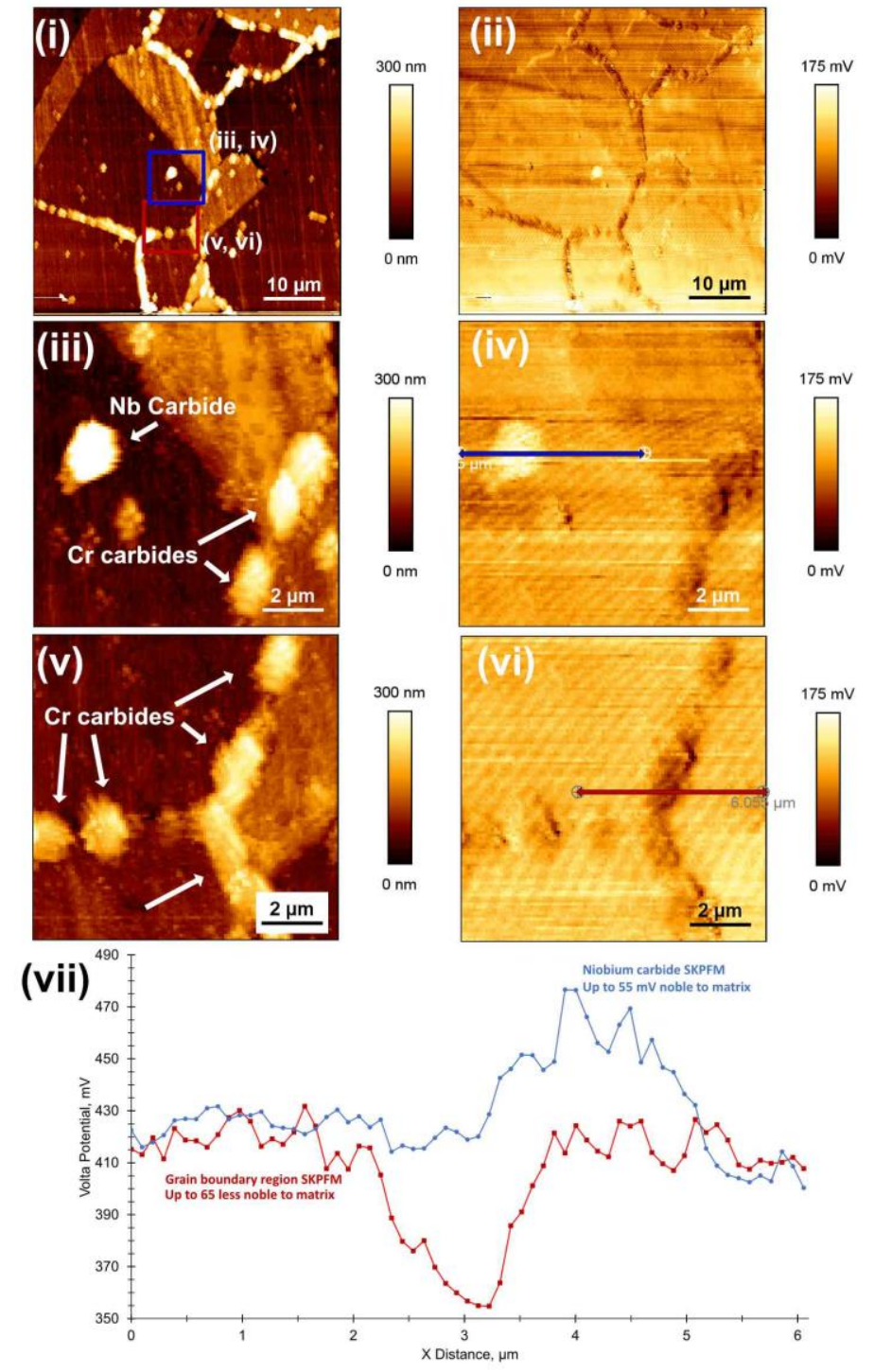

Figure 9: (i, ii) AFM topography and SKPFM Volta potential mapping of the thermally sensitized end cap alloy. (iii, iv) AFM and SKPFM of NbC precipitate shown in the blue box in (i), ( $v$, vi) AFM and SKPFM of sensitized triple point grain boundary shown in the red box in (i), (vii) cross section of the $\mathrm{NbC}$ precipitate (blue line) and sensitized grain boundary region (red line) 
An in-situ TLM experiment was conducted to follow localized corrosion propagation on the thermally sensitized alloy under potentiostatic polarization. Selected still images and magnified views from the experiment are shown in Figure 10(i-vi). Despite being unable to capture the initiation of IGC, the images show the propagation of IGC which appears to have initiated from a crevice site. Propagation of IGC was observed along the sensitized grain boundaries which then propagated around NbC precipitates present along the boundary (Figure 10(iv-vi)).
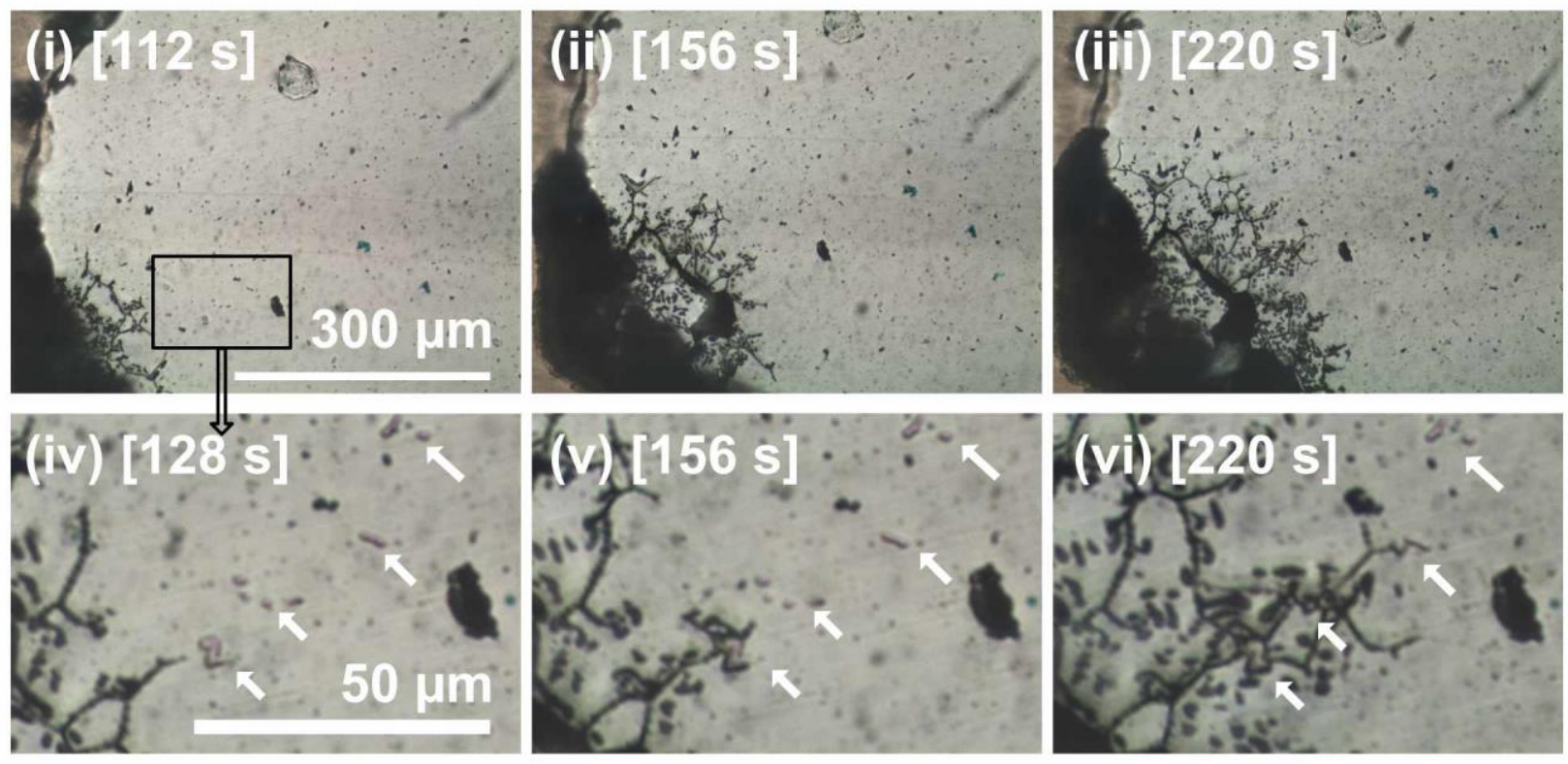

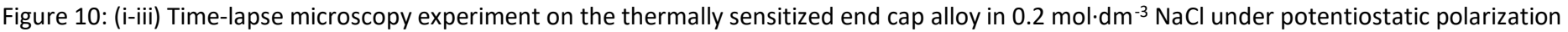
(550 mV SCE). (iv-vi) show magnified views of the area within the black box in (i), with the arrows showing the location of NbC precipitates. Timings are given in square brackets

Figure 11 and Figure 12 show the early stages of localized corrosion initiation on the sensitized alloy (tube material) following

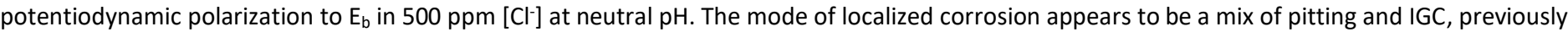
termed intergranular pitting corrosion (IG pitting) ${ }^{8}$. Figure $11(\mathrm{i}$, ii) show the presence of localized corrosion at a grain boundary around a group of precipitates - EDS point analysis confirmed that these were rich in Nb. Figure 12(i, ii) shows another example of IG pit development, again where $\mathrm{NbC}$ are located at a grain boundary, in close vicinity to the grain boundary triple point. It is also clear from the micrographs the locations where $\mathrm{Cr}$ carbides had been removed from the grain boundary, as "pockets" of less than $1 \mu \mathrm{m}$ in diameter along the grain boundary. EDS mapping (Figure 12(iii)) again confirmed that the large white colored precipitates in the backscatter electron micrograph are $\mathrm{Nb}$ and $\mathrm{C}$ rich, indicating that these are likely to be NbC precipitates. Figure 13 shows examples of larger, more-developed IG pits centered around grain boundary intersections. Similar observations were also identified for sensitized end cap flat strip specimens. Figure 14 shows the sensitized end cap flat strip following polarization

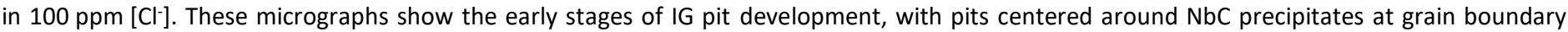
intersections. Figure 15 shows IG pits at different stages following polarization at a lower [Cl-], but elevated temperature. Figure 15(i) shows what appears to be IG pit initiation at NbC precipitates, whilst Figure 15(ii) shows further IG pit development at a cluster of NbC precipitates present at a grain boundary triple point. Figure 15(iii, iv) show a well-developed IG pit with NbC precipitates present at the pit center. Finally, Figure 15 (v, vi) shows later stages of IG pit propagation. 


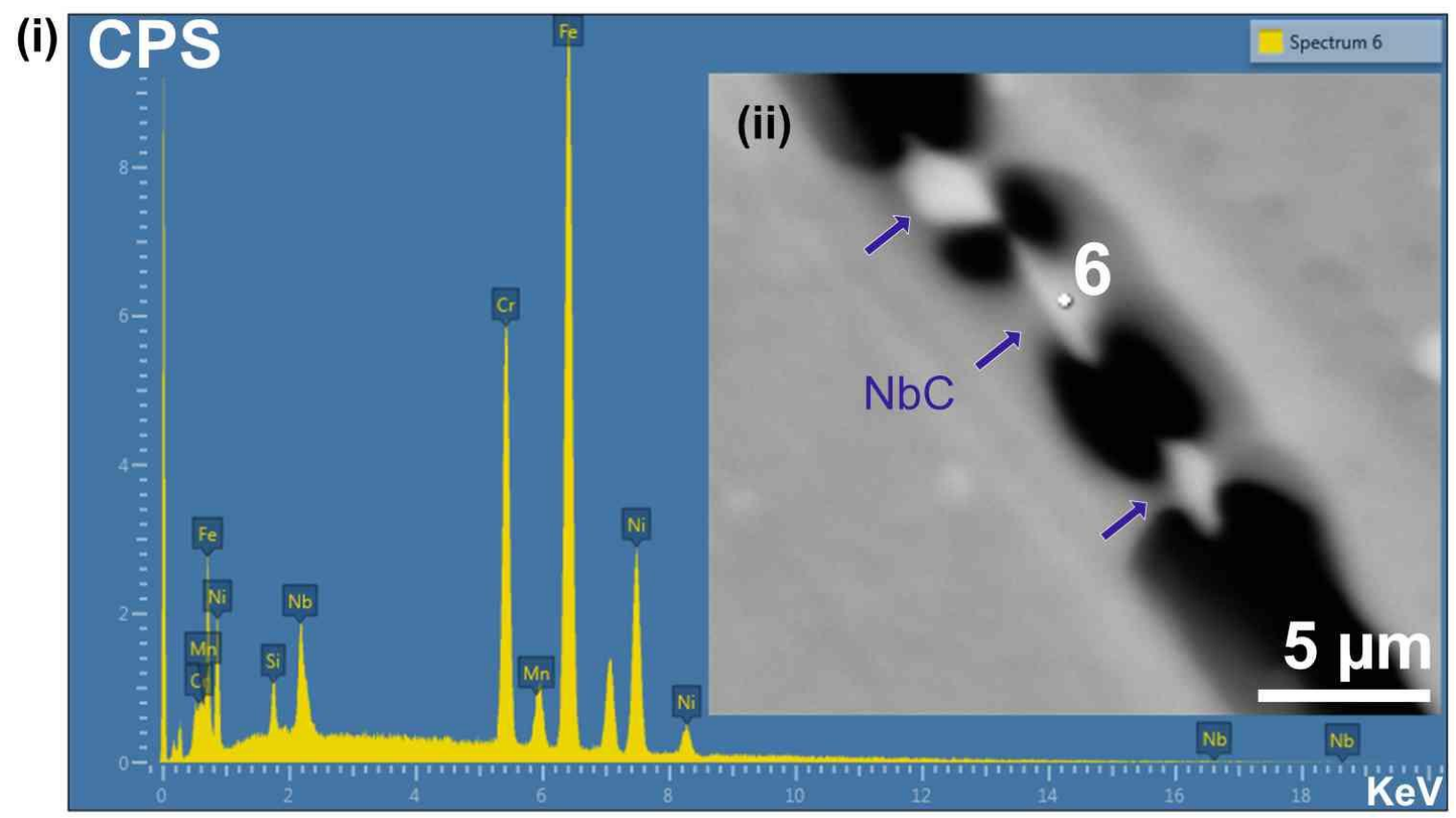

Figure 11: Sensitized tube following potentiodynamic polarization to $E_{b}$ in $500 \mathrm{ppm} \mathrm{[Cl-]} \mathrm{at} \mathrm{pH} \mathrm{7.} \mathrm{(i)} \mathrm{EDS} \mathrm{point} \mathrm{spectrum} \mathrm{from} \mathrm{location} 6$ marked in (ii). (ii) $\mathrm{NbC}$ precipitates present at a sensitized grain boundary
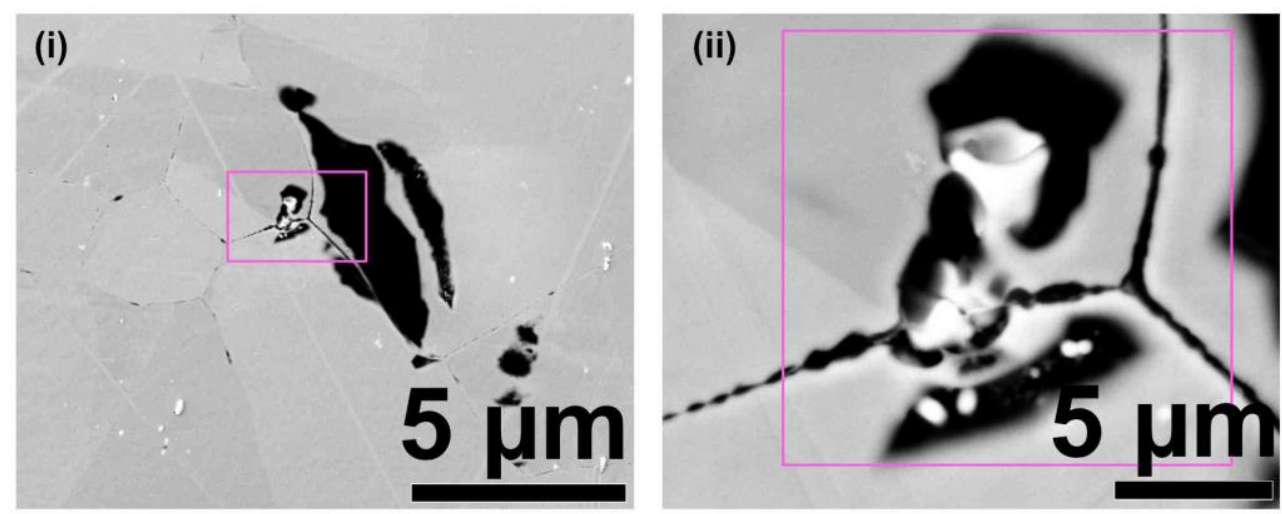

(iii)
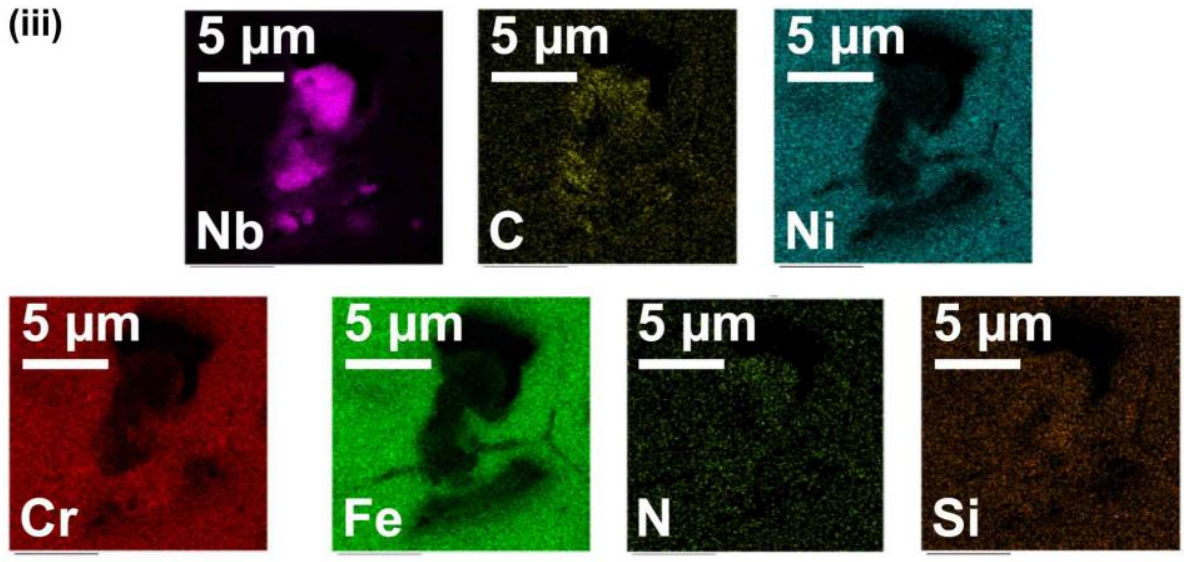

Figure 12: Electron micrographs of sensitized tube specimens following potentiodynamic polarization to $\mathrm{E}_{\mathrm{b}}$ in $500 \mathrm{ppm}$ [Cl-] at pH 7. (i) intergranular pit formation with $\mathrm{NbC}$ precipitates located in close vicinity to a sensitized grain boundary, (ii) magnified area denoted in the purple box in (ii). (iii) EDS mapping analysis of the purple box area denoted in (ii) 

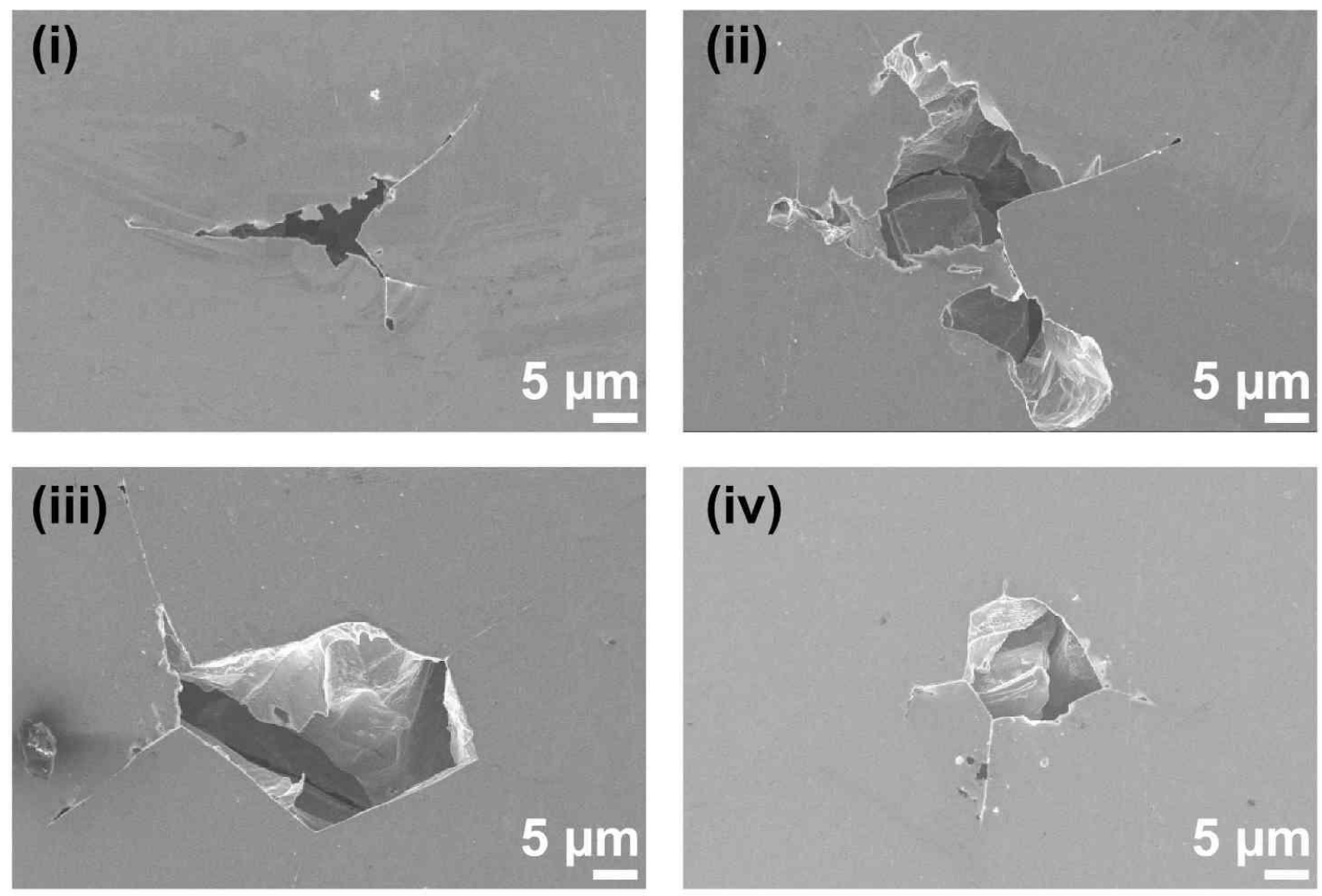

Figure 13: IG pitting corrosion on sensitized tube metal after polarization in $500 \mathrm{ppm}\left[\mathrm{Cl}^{-}\right]$at $\mathrm{pH} 7$

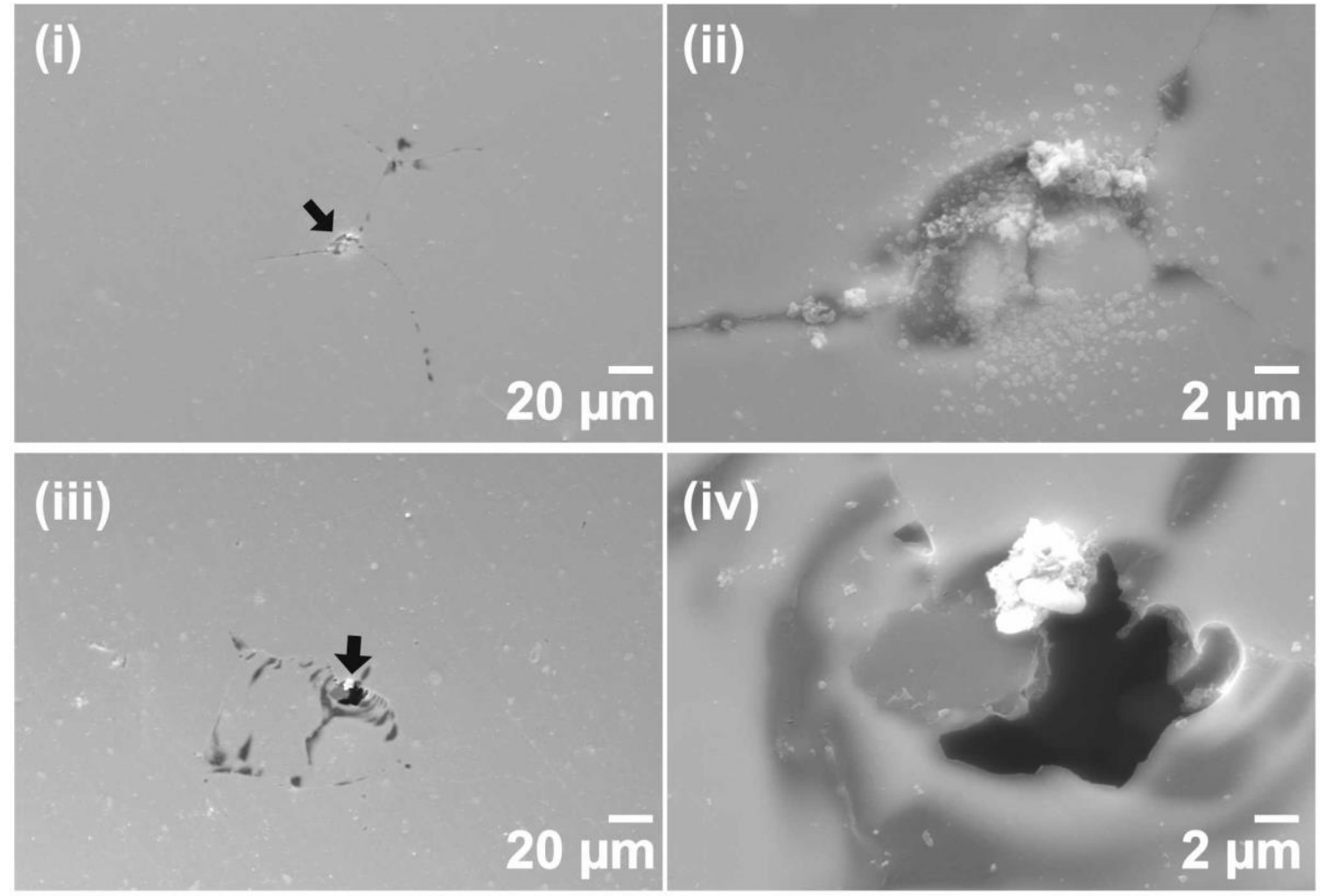

Figure 14: Secondary electron images of intergranular pits on thermally sensitized end cap alloy following potentiodynamic polarization past breakdown in 100 ppm [Cl-] at pH 7. The initiation sites at NbC precipitates are highlighted by the black arrows (i, iii) low magnification, (ii, iv) higher magnification 

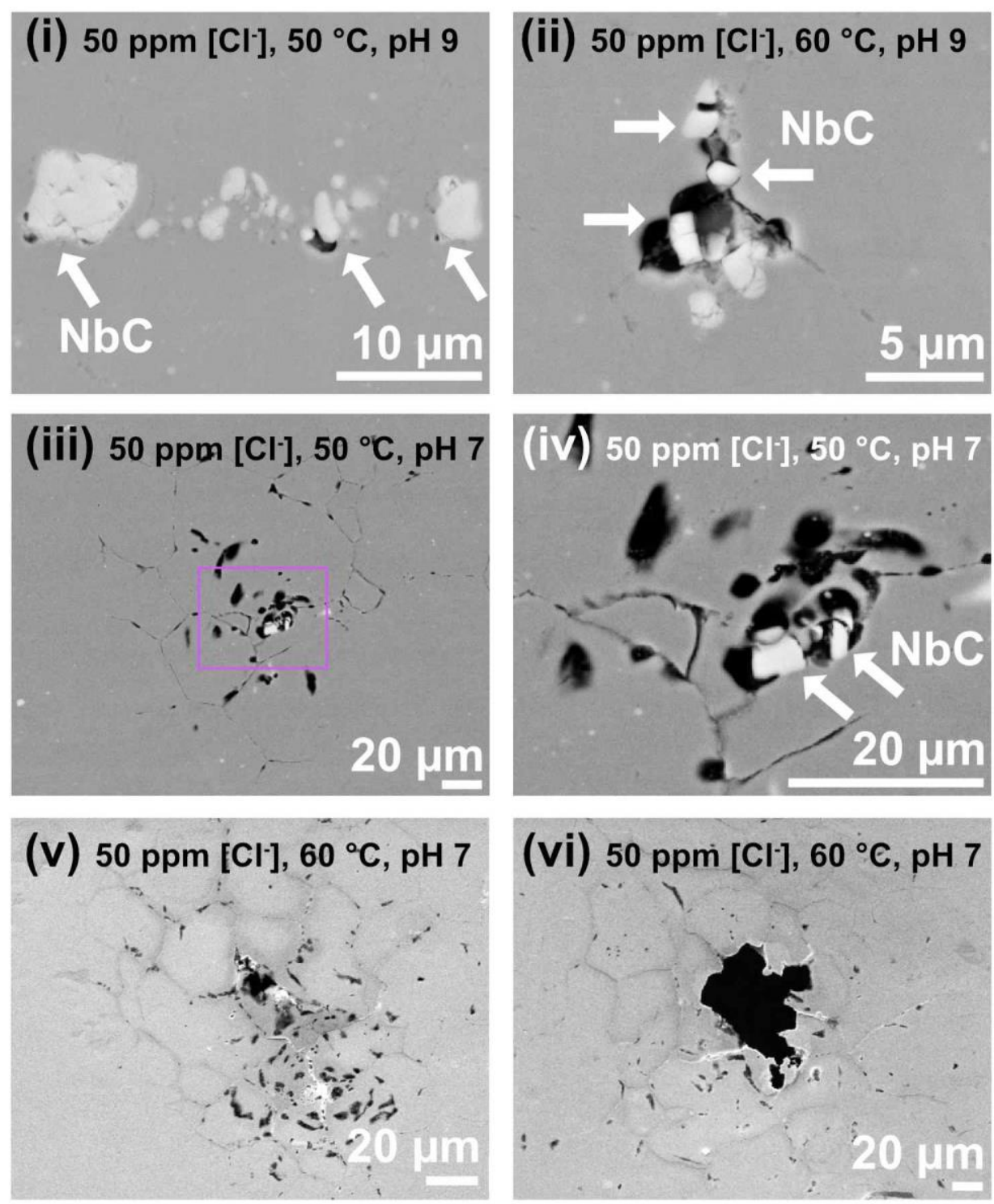

Figure 15: Sensitized end cap alloy following polarization in $50 \mathrm{ppm}[\mathrm{Cl}-]$ at 50 and $60^{\circ} \mathrm{C}$ at $\mathrm{pH} 9$ and $\mathrm{pH}$ 7. A magnified view of the area denoted by the purple box in image (iii) is shown in image (iv)

\section{DISCUSSION}

Potentiodynamic polarization of the as-received, unsensitized, $20 \mathrm{Cr}-25 \mathrm{Ni}-\mathrm{Nb}$ end-cap sample material showed that it had a lower $\mathrm{Cl}^{-}$ dependence on $\mathrm{E}_{\mathrm{b}}$ (-0.098 V/decade) when compared to other austenitic stainless steels such as AISI 316L (EN 1.4404 / UNS S31603) and AISI 904L (EN 1.4539 / UNS N08904). ${ }^{26}$ Though AISI $904 \mathrm{~L}$ is higher alloyed, viii compared to AISI 316L, both stainless steels had a Cl- dependence on $\mathrm{E}_{\mathrm{b}}$ of $-0.14 \mathrm{~V} /$ decade, however the AISI $316 \mathrm{~L}$ was displaced by up to $0.24 \mathrm{~V}$ negative of $904 \mathrm{~L} .{ }^{26}$ Williams and $\mathrm{McMurray}^{20}$ state the same $\mathrm{Cl}^{-}$dependence of $-0.14 \mathrm{~V} /$ decade for turbine blade steels ( 11.5 and $13.5 \mathrm{wt} . \% \mathrm{Cr}$ ). Laycock ${ }^{27}$ quoted values of $-0.090 \mathrm{~V} /$ decade for AISI 302 stainless steel (EN 1.4310 / UNS S30200, similar in composition to 316, but without Mo) prepared to a 120 grit surface finish. Rudimentary investigation of the Laycock data indicates that the AISI 302 curve is displaced by $0.4 \mathrm{~V}$ negative of the results shown here for $20 \mathrm{Cr}-25 \mathrm{Ni}-\mathrm{Nb}$ stainless steel. The results displayed here therefore lead to the conclusion that the unsensitized $20 \mathrm{Cr}-25 \mathrm{Ni}-\mathrm{Nb}$ exhibits a $\mathrm{Cl}^{-}$dependence similar to that of AISI 302 stainless steel but is more

\footnotetext{
viii Super austenitic AISI 904L has a similar high $\mathrm{Cr}$ and Ni content to $20 \mathrm{Cr}-25 \mathrm{Ni}-\mathrm{Nb}$ (19-23 Wt \% and 23-28 Wt \% respectively), but alloyed with a high amount of Mo $(4-5 \mathrm{Wt} \%)$
} 
resistant to corrosion (i.e., greater $E_{b}$ for a given $\left[\mathrm{Cl}^{-}\right]$). At temperatures below the critical pitting temperature (CPT), salt films are prevented from forming, whereas at temperatures above CPT salt films may precipitate, allowing for stable pitting. ${ }^{28}$ Temperature dependence of AISI 304 , AISI 316 and AISI 904L austenitic stainless steels was studied by Laycock and Newman ${ }^{27}$ in $1 \mathrm{~mol} \cdot \mathrm{dm}^{-3} \mathrm{NaCl}$ above CPT ( 0, 5, $50{ }^{\circ} \mathrm{C}$ respectively). They observed that for these alloys there was only a weak dependence on temperature; with B parameters (i.e. temperature dependence) of $-2.9,-3.8,-3.3 \mathrm{mV} \cdot \mathrm{K}^{-1}$, for AISI 304, AISI 316 and AISI 904L respectively. Malik et al ${ }^{29}$ also studied the temperature dependence of AISI 316L (EN 1.4404, UNS S31603) and observed $\mathrm{B}=-3.7 \mathrm{mV} \cdot \mathrm{K}^{-1}$, although this was in a far more diluted electrolyte $\left(1000 \mathrm{ppm}\left[\mathrm{Cl}^{-}\right] \mathrm{c} . \mathrm{f} .1 \mathrm{~mol} \cdot \mathrm{dm} \mathrm{m}^{-3}\right)$. Comparing the results for the $\mathrm{B}$ parameter from that which was observed by Laycock and Newman, ${ }^{27}$ and Melik et al ${ }^{29}$ the results presented here show a very strong temperature dependence, being double that observed in the past works $\left(-7.3 \mathrm{mV} \cdot \mathrm{K}^{-1}\right)$, although these were for different austenitic alloys. There is little information in the open literature relating to the dependence on $\left[\mathrm{Cl}^{-}\right]$, temperature and $\mathrm{pH}$ for the $20 \mathrm{Cr}-25 \mathrm{Ni}-\mathrm{Nb}$ alloy discussed in this paper. Howett et al ${ }^{14}$ published a small number of potentiodynamic curves relating to the effect of temperature on the unsensitized $20 \mathrm{Cr}-25 \mathrm{Ni}-\mathrm{Nb}$ alloy, albeit at a much reduced [Cl-] $(\sim 1$ $\mathrm{ppm}$ ) and elevated $\mathrm{pH}(11.4)$ to reflect a typical storage pond environment. This did make a comparison possible; and rudimentary investigation of the Howett et al data indicates a B parameter of $\sim-5 \mathrm{mV} \cdot \mathrm{K}^{-1}$, which is again slightly lower than that reported here.

The simple PREN calculation accounts for the beneficial impact of alloying elements: $\mathrm{Cr}$ which is the passivating element within a stainless steel, as well as Mo and N. Given that it is a simple calculation, it cannot be used to predict the performance in any given environment. ${ }^{30}$ For example, $\mathrm{Ni}$ is not taken into account, and no consideration is given for detrimental residual elements, for example Mn and S which form MnS inclusions, which can lead to poor corrosion properties. Neither does the PREN account for mechanical processing (e.g. residual stress through cold working), thermal processing of the alloy (e.g. sensitization) or any grain boundary engineering effects. The PREN nevertheless has been used as a qualitative means of comparing the corrosion performance of the $20 \mathrm{Cr}-25 \mathrm{Ni}-\mathrm{Nb}$ alloy in comparison to AISI 302,304 , and 316 stainless steels, alongside d.c.

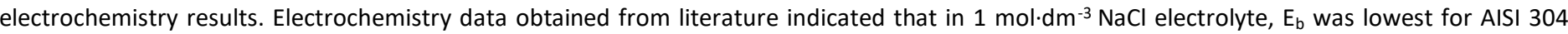
stainless steel, followed by AISI 302 and AISI 316. These findings are consistent with PREN values, given the minimum and maximum Cr specification for AISI 302 and AISI 304 (17-19 Wt. \% compared to 18-20 Wt. \%). The 20Cr-25Ni-Nb alloy had a higher $E_{b}$ than the commercial austenitic stainless steel grades (AISI 302, 304 and 316) as shown in Figure 3, and as previously discussed, has a lower [Cl-] dependence compared to AISI 316L. The PREN calculation for $20 \mathrm{Cr}-25 \mathrm{Ni}-\mathrm{Nb}$ on its own would however indicate that its corrosion resistance would be comparable to AISI 302 , and lower than that of AISI 316. This discrepancy between the PREN calculation and the electrochemical data may be explained by the disregard of Ni within the PREN calculation. Whilst $\mathrm{Ni}$ is a austenite stabilizer ${ }^{31}$ it is also very beneficial for localized corrosion resistance following depassivation of the alloy, though no significant effects have been identified with additions beyond $20 \mathrm{Wt}$. $\%{ }^{22,32,33} 20 \mathrm{Cr}-25 \mathrm{Ni}-\mathrm{Nb}$ stainless steel has increased $\mathrm{Ni}$ content compared to the other stainless steels discussed here: $25 \mathrm{Wt}$ \% compared to 10-14 Wt. \% in AISI 316, and 8-10 Wt. \% in AISI 302 and AISI 304.

As observed in prior studies, $, 8,16,25,34 \mathrm{NbC}$ precipitates in this $20 \mathrm{Cr}-25 \mathrm{Ni}-\mathrm{Nb}$ alloy do not dissolve preferentially. Imaging of as-received and stabilized specimens following corrosion experiments in current work shows that localized corrosion can initiate around NbC precipitates, which can then develop into pits. In some instances, what appeared to be small crevices/cracks were found adjacent to NbC precipitates, which could be a contributing factor to stable pit initiation. Post corrosion observation of the stabilized microstructure showed that pitting also initiated around NbC precipitates, and that more-developed pits formed lacy covers which assist in pit stability. This confirms the baseline expectation, that in the non-sensitized alloy the corrosion mechanism is pitting, which occurs around $\mathrm{NbC}$ precipitates. The findings for the thermally sensitized alloy are now considered. Corrosion site mapping using SKPFM showed that NbC precipitates have positive Volta potentials in relation to the matrix and sensitized grain boundary regions. Note, Volta potentials from SKPFM do not give information on kinetics, and so the in-situ TLM experiment effectively confirms that the sensitized grain boundary region is susceptible to corrosion, whilst the NbC precipitates are noble. From the SKPFM results, the low Volta 
potential regions appear to coincide with the high topography regions. This would indicate that the low potentials may be from $\mathrm{Cr}$ carbides at the grain boundaries, as opposed to the Cr-depleted zones around them, though, higher resolution mapping would likely be required to discern between the two. As illustrated with SEM micrographs of post-corrosion surfaces, NbC precipitates, when present at, or in the vicinity of a sensitized grain boundary, act as initiation sites for localized corrosion. $\mathrm{NbC}$ precipitates therefore act as localized corrosion initiation sites when the alloy is thermally sensitized, just as they do when unsensitized. The key difference here, however, is that these pits appear to link with Cr-depleted grain boundary regions. This was found to be the case in multiple examples shown in this paper, by different institutions. It is postulated therefore that once corrosion initiates as a pit around $\mathrm{NbC}$ precipitates close to, or at a grain boundary, corrosion then propagates along the sensitized grain boundaries by IGC. The localized corrosion mechanism has characteristics of pitting corrosion, and IGC, and can be referred to as IG pitting. Such IG pitting was observed by Burnett et al. ${ }^{35}$ who found IGC emanating from the sides and bottom of corrosion pits on Type $316 \mathrm{H}$ austenitic stainless steel following polarization in $0.1 \mathrm{~mol} \cdot \mathrm{dm}^{-3} \mathrm{NaCl}$ using correlative tomography techniques. Whilst the mode of corrosion is clearly a combination of pitting and IGC, this contrasts with the TLM images, which appeared more typical of IGC. With the TLM example, corrosion initiated at a crevice site, with IGC propagating along the free surface, not dissimilar to the corrosion morphology witnessed with IG pitting. A similar finding was published by Laferrere et al. ${ }^{36}$ with SVET and post-corrosion optical microscopy, showing IGC propagating away from a crevice site with thermally sensitized $20 \mathrm{Cr}$ - $25 \mathrm{Ni}-\mathrm{Nb}$. In combining the evidence from not only this work, but with prior investigations, it is postulated that in the sensitized alloy, when NbC precipitates are located at, or in close vicinity of a sensitized grain boundary, or indeed grain boundary intersections, corrosion first initiates around the periphery of the precipitate. This then proceeds to propagate along sensitized grain boundaries. We know from observations of the surfaces following corrosion experiments, that IG pit initiation consistently occurs around these $\mathrm{NbC}$ precipitates. A basic hypothesis for the reason why corrosion initiation occurs at these sites is now given. The SKPFM analysis showed that there was a Volta potential difference between sensitized grain boundary regions and NbC of $\sim 100 \mathrm{mV}$, which could allow a galvanic couple to form - with the $\mathrm{NbC}$ being noble with respect to the sensitized grain boundary region. As experiments within this publication have been performed under external anodic polarization, micro galvanic coupling cannot occur, as all of the cathodic current would be passed at the counter electrode. As such, another reason for corrosion initiation is required as micro galvanic coupling is not plausible when under external potential control. One possibility is that the $\mathrm{NbC}$ precipitates act as local stress raisers; meaning that passive films within the region of $\mathrm{NbC}$ precipitates are less protective than other regions of the surface.

Industry experience through post storage examination, along with irradiated coupon corrosion experiments, has shown that the failure mode for $20 \mathrm{Cr}$-25Ni-Nb cladding is IGC, which leads to IGSCC in the presence of stress ${ }^{\left({ }^{\left(x_{1}\right.}\right), 3,9,37,38}$ Stresses in the cladding material may arise from a combination of factors, such as fuel pellet swelling / bonding / fracturing, pellet-clad differential thermal expansion, and in-reactor thermal pressurization of the AGR pin fill gas (helium). ${ }^{9}$ Note that such spent AGR fuel has been exposed to $\mathrm{NaOH}$-dosed ponds for over 35 years with no observed corrosion during storage. ${ }^{3,38}$ The key finding of this research is that for both the non-sensitized and sensitized forms on the alloy, initiation occurs at the same sites - adjacent to $\mathrm{NbC}$ precipitates, as pit like features - and does not appear to be influenced by $\mathrm{Cr}$ depletion. This does not occur because of micro galvanic coupling between the precipitate and sensitized grain boundary region. This could possibly be due to the $\mathrm{NbC}$ precipitates acting as local stress raisers, which leads to less protective passive films in these regions. If the pit eventually impinges on a Cr depleted region, localized corrosion continues to propagate, however not as pitting, but in the form of IGC. These findings link to industry operating experience, and assists in explaining potential precursor stages to IGC, and - with sufficient stress - IGSCC. These observations have been made on thermally

(ix) Pitting has been observed historically with cold worked cladding in abnormal conditions. This is not considered to be of concern when pond operating parameters are well controlled. ${ }^{3}$ 
sensitized $20 \mathrm{Cr}-25 \mathrm{Ni}-\mathrm{Nb}$ stainless steel AGR fuel cladding, and thus are not fully representative of ex-service cladding which will have undergone many years of neutron irradiation.

\section{CONCLUSIONS}

$>$ In this paper $\left[\mathrm{Cl}^{-}\right], \mathrm{pH}$, and temperature dependence curves have been obtained for unsensitized, unirradiated $20 \mathrm{Cr}-25 \mathrm{Ni}-\mathrm{Nb}$ stainless steel advanced gas-cooled reactor (AGR) fuel cladding.

$>$ Corrosion site mapping has been undertaken using scanning Kelvin probe force microscopy (SKPFM) to assess the susceptibility for different phases to undergo aqueous corrosion. It has been found that nobility is in the following order: niobium carbide (NbC) precipitates $>$ matrix $>$ sensitized grain boundary regions.

$>$ Micro galvanic coupling between $\mathrm{NbC}$ precipiates and sensitized grain boundary regions is not the reason for corrosion initiation at the periphery of $\mathrm{NbC}$ precipitates, as all experiments were performed under external anodic polarization. It is postulated that $\mathrm{NbC}$ precipitates act as stress raisers, and as a consequence, the passive film is less protective than other regions of the surface.

$>$ Time-lapse microscopy (TLM) showed the propagation of intergranular corrosion along sensitized grain boundaries, and the nobility of NbC precipitates, confirming the SKPFM analysis. In addition, ex-situ SEM-EDS was used to ascertain the link between pits and IGC.

$>$ A hypothesis has been provided to assist in linking IG pit initiation at NbC precipitates, with IGC and IGSCC. Localized corrosion initiation with the unsensitized / stabilized alloy takes the form of pitting, whilst in the thermally sensitized condition, it takes the form of IG pitting at the same sites, as pit-like features, in close vicinity to NbC precipitates. This does not appear to be influenced by $\mathrm{Cr}$ depletion; however, should a pit impinge on a $\mathrm{Cr}$ depleted grain boundary region, localized corrosion propagates in the form of IGC.

\section{ACKNOWLEDGMENTS}

The authors wish to thank the UK National Nuclear Laboratory for providing funding through the Core Science Program, the UK Nuclear Decommissioning Authority for providing PhD funding for Ronald Clark and May Chan, and to Westinghouse, UK for supplying the sample material. The authors acknowledge support from the Materials Research Centre at Swansea University, UK. The authors thank the Engineering and Physical Sciences Research Council (EPSRC) for funding through the Centre for Doctoral Training in Advanced Metallic Systems at the University of Manchester [EP/G036950/1].

\section{REFERENCES}

1. Hitchcock P, Fisher S. Mechanical Testing of Civil Advanced Gas-Cooled Reactor Tie Bars. Effects of Radiation on Materials: 15th International Symposium. 2009:64-64-12. doi:10.1520/stp17862s

2. Nuclear Decommissioning Authority. Oxide Fuels Credible Options. SMS/TS/C2-OF/001/Credible Options; 2011.

3. Hambley DI. Technical basis for extending storage of the UK's advanced gas-cooled reactor fuel. International Nuclear Fuel Cycle Conference, GLOBAL 2013: Nuclear Energy at a Crossroads. 2013;2(September 2013):1161-1170.

4. Norris D, Baker C, Taylor C, Titchmarsh J. Radiation-Induced Segregation in $20 \mathrm{Cr} / 25 \mathrm{Ni} / \mathrm{Nb}$ Stainless Steel. In: Stoller RE, Kumar AS, Gelles DS, eds. Effects of Radiation on Materials: 15th International Symposium. 100 Barr Harbor Drive, PO Box C700, West Conshohocken, PA 19428-2959: ASTM International; 1992:603-603-618. doi:10.1520/STP17898S

5. Norris D, ed. Compositional Profiles at Grain Boundaries in $20 \% \mathrm{Cr} / 25 \% \mathrm{Ni} / \mathrm{Nb}$ Stainless Steel. In: Symposium on Radiation-Induced 
Sensitisation of Stainless Steels; Berkeley (UK). INIS-GB--90; 1987:86-98.

6. Okamoto PR, Rehn LE. Radiation-induced segregation in binary and ternary alloys. Journal of Nuclear Materials. 1979;83(1):2-23. doi:10.1016/0022-3115(79)90587-7

7. Was GS, Andresen PL. Irradiation Assisted Corrosion and Stress Corrosion Cracking (IAC/IASCC) in Nuclear Reactor Systems and Components. Woodhead Publishing Limited; 2012. doi:10.1533/9780857095343.2.131

8. Clark RN, Searle J, Martin TL, Walters WS, Williams G. The role of niobium carbides in the localised corrosion initiation of $20 \mathrm{Cr}-25 \mathrm{Ni}-\mathrm{Nb}$ advanced gas-cooled reactor fuel cladding. Corrosion Science. 2020;165:108365. doi:10.1016/j.corsci.2019.108365

9. Whillock GOH, Hands BJ, Majchrowski TP, Hambley DI. Investigation of thermally sensitised stainless steels as analogues for spent AGR fuel cladding to test a corrosion inhibitor for intergranular stress corrosion cracking. Journal of Nuclear Materials. 2018;498:187-198. doi:10.1016/j.jnucmat.2017.10.017

10. Barcellini C, Harrison RW, Dumbill S, Donnelly SE, Jimenez-Melero E. Evolution of radiation-induced lattice defects in 20/25 Nb-stabilised austenitic stainless steel during in-situ proton irradiation. Journal of Nuclear Materials. 2019;514:90-100. doi:10.1016/j.jnucmat.2018.11.019

11. Barcellini C, Dumbill S, Jimenez-Melero E. Recrystallisation behaviour of a fully austenitic Nb-stabilised stainless steel. Journal of Microscopy. 2019;274(1):3-12. doi:10.1111/jmi.12776

12. Barcellini C, Harrison RW, Dumbill S, Donnelly SE, Jimenez-Melero E. Local chemical instabilities in $20 \mathrm{Cr}-25 \mathrm{Ni} \mathrm{Nb}-\mathrm{stabilised}$ austenitic stainless steel induced by proton irradiation. Journal of Nuclear Materials. 2019;518:95-107. doi:10.1016/j.jnucmat.2019.02.035

13. Barcellini C, Dumbill S, Jimenez-Melero E. Isothermal annealing behaviour of nuclear grade $20 \mathrm{Cr}-25 \mathrm{Ni}$ austenitic stainless steel. Materials Characterization. 2018;145:303-311. doi:10.1016/j.matchar.2018.08.057

14. Howett E, Boxall C, Hambley DI. AGR Cladding Corrosion: Investigation of the Effect of Temperature on Unsensitized Stainless Steel. MRS Advances. 2017;2(11):615-620. doi:10.1557/adv.2016.651

15. Howett EA, Boxall C, Wilbraham RJ, Hambley DI. The behavior of advanced gas reactor simulated spent nuclear fuels in wet interim storage conditions. Progress in Nuclear Science and Technology. 2018;5(0):140-143. doi:10.15669/pnst.5.140

16. Clark RN, May Chan C, Martin TL, et al. The Effect of Sodium Hydroxide on Niobium Carbide Precipitates in Thermally Sensitised 20Cr-25NiNb Austenitic Stainless Steel. Corrosion Science. 2020:108596. doi:10.1016/j.corsci.2020.108596

17. Clark RN, Burrows R, Patel R, Moore S, Hallam KR, Flewitt PEJ. Nanometre to micrometre length-scale techniques for characterising environmentally-assisted cracking: An appraisal. Heliyon. 2020;6(3):e03448. doi:10.1016/j.heliyon.2020.e03448

18. Clark RN. Mapping of Corrosion Sites in Advanced Gas-cooled Reactor Fuel Cladding in Long Term Pond Storage. 2018. doi:10.23889/SUthesis.40783

19. Hibbert DB, James AM. Dictionary of Electrochemistry. 2nd ed. London, UK: Macmillan; 1984. doi:10.1016/0026-265X(86)90093-7

20. Williams G, McMurray HN. Pitting Corrosion of Steam Turbine Blading Steels: The Influence of Chromium Content, Temperature, and Chloride Ion Concentration. CORROSION. 2006;62(3):231-242. doi:10.5006/1.3278269

21. Newman RC. Understanding the corrosion of stainless steel. Corrosion. 2001;57(12):1030-1041. doi:10.5006/1.3281676

22. Malik AU, Siddiqi NA, Ahmad S, Andijani IN. The effect of dominant alloy additions on the corrosion behavior of some conventional and high alloy stainless steels in seawater. Corrosion Science. 1995;37(10):1521-1535. doi:10.1016/0010-938X(95)00043-J

23. Laycock NJ, Newman RC. Localised dissolution kinetics, salt films and pitting potentials. Corrosion Science. 1997;39(10-11):1771-1790. doi:10.1016/S0010-938X(97)00049-8

24. Navai F. Electrochemical behaviour of a type 302 stainless steel in a stress field. Journal of Materials Science. 2000;35(23):5921-5925. doi:10.1023/A:1026705819584

25. Chan CM, Engelberg DL, Walters WS. Performance Characterisation of AGR Fuel Cladding Relevant to Long-term in-Pond Storage in pHmoderated Aqueous Environment. In: TopFuel 2015 Proceedings - Part II. ; 2015:120-129.

26. Meguid EAA El, Gouda VK, Mahmoud NA. Pitting Corrosion Behaviour of Type SUS904L and SUS316L Stainless Steels in Chloride Solutions. Materials Transactions, JIM. 1994;35(10):699-702. doi:10.2320/matertrans1989.35.699

27. Laycock NJ, Newman RC. Temperature dependence of pitting potentials for austenitic stainless steels above their critical pitting temperature. Corrosion Science. 1998;40(6):887-902. doi:10.1016/S0010-938X(98)00020-1

28. Li T, Scully JR, Frankel GS. Localized Corrosion: Passive Film Breakdown vs Pit Growth Stability: Part II. A Model for Critical Pitting Temperature. Journal of The Electrochemical Society. 2018;165(9):C484-C491. doi:10.1149/2.0591809jes

29. Malik AU, Mayan Kutty PC, Siddiqi NA, Andijani IN, Ahmed S. The influence of $\mathrm{pH}$ and chloride concentration on the corrosion behaviour of AISI 316L steel in aqueous solutions. Corrosion Science. 1992;33(11):1809-1827. doi:10.1016/0010-938X(92)90011-Q

30. Cleland JH. What does the pitting resistance equivalent really tell us? Engineering Failure Analysis. 1996;3(1):65-69. doi:10.1016/13506307(95)00026-7

31. Iversen A, Leffler B. Aqueous Corrosion of Stainless Steels. In: Sheir's Corrosion. 3rd ed. Elsevier B. V.; 2010:1802-1877. doi:https://doi.org/10.1016/B978-044452787-5.00091-3

32. Revie RW, Uhlig HH. Alloying for Corrosion Resistance; Stainless Steels. In: Revie RW, Uhlig HH, eds. Corrosion and Corrosion Control. John Wiley \& Sons Inc.; 2008:333-365. doi:10.1002/9780470277270.ch19

33. Avesta Sheffield. Corrosion Handbook. Sandvikens Tryckeri; 1994.

34. Phuah $\mathrm{CH}$. Corrosion of Thermally-aged Advanced Gas-cooled Reactor Fuel Cladding. Thesis. 2012. http://hdl.handle.net/10044/1/10550.

35. Burnett TL, McDonald SA, Gholinia A, et al. Correlative Tomography. Scientific Reports. 2015;4(1):4711. doi:10.1038/srep04711

36. Laferrere A, Burrows R, Glover C, et al. In situ imaging of corrosion processes in nuclear fuel cladding. Corrosion Engineering Science and Technology. 2017;52(8):596-604. doi:10.1080/1478422X.2017.1344038

37. Morgan S, Hambley DI, Foster R, et al. Post Irradiation Examination of UK Advanced Gas-cooled Reactor Fuel Cladding ( post- reactor and post-storage). In: 52nd HOTLAB Conference 2015. ; 2015.

38. Al-Shater A, Engelberg DL, Lyon S, et al. Characterization of the stress corrosion cracking behavior of thermally sensitized $20 \mathrm{Cr}-25 \mathrm{Ni}$ stainless steel in a simulated cooling pond environment. Journal of Nuclear Science and Technology. 2017;54(7):742-751.

doi:10.1080/00223131.2017.1309305 
39. Anwyl C, Boxall C, Wilbraham R, Hambley DI, Padovani C. Corrosion of AGR Fuel Pin Steel Under Conditions Relevant to Permanent Disposal. Procedia Chemistry. 2016;21:247-254. doi:10.1016/j.proche.2016.10.035

40. Laycock NJ, Moayed MH, Newman RC. Metastable Pitting and the Critical Pitting Temperature. Journal of The Electrochemical Society. 1998;145(8):2622-2628. doi:10.1149/1.1838691 